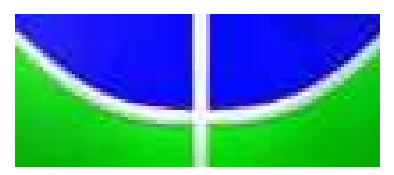

UNIVERSIDADE DE BRASÍLIA - UnB

Centro de Excelência em Turismo - CET

Pós-graduação Lato Sensu

Curso de Especialização em Tecnologia de Alimentos

TÂNYA SULAMYTHA BEZERRA

\title{
DESIDRATAÇÃO DE HORTALIÇAS: ASPECTOS TEÓRICOS
}

Brasília-DF

Março, 2007. 


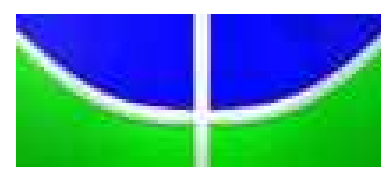

\author{
UNIVERSIDADE DE BRASÍLIA - UnB \\ Centro de Excelência em Turismo - CET
}

Pós-graduação Lato Sensu

Curso de Especialização em Tecnologia de Alimentos

TÂNYA SULAMYTHA BEZERRA

\title{
DESIDRATAÇÃO DE HORTALIÇAS: ASPECTOS TEÓRICOS
}

Monografia apresentada como requisito parcial à obtenção do grau de Especialista em Tecnologia de Alimentos, Curso de Especialização lato senso em Tecnologia de Alimentos, do Centro de Excelência em Turismo da Universidade de Brasília.

Orientador: Profō. Msc. Luiz Antônio Borgo

Brasília - DF

Março, 2007. 
BEZERRA, Tânya Sulamytha

Desidratação de Hortaliças: aspectos teóricos / Tânya Sulamytha Bezerra. - Brasília, 2007.

$53 \mathrm{f}$.

Monografia (Curso de Especialização em Tecnologia de Alimentos) Universidade de Brasília, Centro de Excelência em Turismo, 2007.

Orientador: Luiz Antônio Borgo

Área de concentração: Conservação de Alimentos

1. Alimentos 2. Alimentos - Conservação 3. Alimentos-Microbiologia 


\author{
UNIVERSIDADE DE BRASÍLIA - UnB \\ Centro de Excelência em Turismo - CET \\ Pós-graduação Lato Sensu \\ Curso de Especialização em Tecnologia de Alimentos
}

TÂNYA SULAMYTHA BEZERRA

\title{
DESIDRATAÇÃO DE HORTALIÇAS: ASPECTOS TEÓRICOS
}

Aprovada por:

Profo. . Orientador: Ms. Luiz Antônio Borgo

Professor: Msc. Antônio José Rezende

Professora: Dra. Wilma Maria Coelho Araújo

Brasília, 08 de março de 2007. 
Dedico este trabalho a minha mãe, Natália Maria de Lima, a quem devo tudo. O máximo de palavras possíveis ainda se mostram insuficientes para expressar a minha eterna gratidão. Quero dizer, principalmente, que eu a amo muito. 


\section{AGRADECIMENTOS}

A Deus, por me mostrar à luz nos momentos difícies da minha vida e por colocar no meu caminho pessoas maravilhosas, mostrando-me que nada acontece por acaso.

À minha mamãe, Natália, pelo amor incondicional, ensinamentos e por acreditar que eu posso ir além.

À minha família pelo carinho, confiança e apoio.

Às tias, Maria Pia e Maria Wilma, pela assistência e afeição durante todo o curso.

Ao Profo Msc. Luiz Antônio Borgo pela atenção, disponibilidade e carinho dedicado para correção e sugestões que tanto contribuíram para a realização deste trabalho.

Aos demais professores do curso de especialização em Tecnologia de Alimentos, que contribuíram para ampliação dos meus conhecimentos científicos.

À amiga Anamarina pela solidariedade constante, amizade, carinho e boa convivência durante todo o curso.

Aos amigos da turma, em especial Adriana, Aldemir, Ana Rita, Gisele, Márcio, Raquel e Rayane pelas conversas, alegrias compartilhadas e companheirismo na vida acadêmica.

A todos que contribuíram direto ou indiretamente para conclusão deste trabalho. 
Momentos na Vida

"[...] A felicidade aparece para aqueles Que choram. Para aqueles que se machucam.

Para aqueles que buscam e tentam sempre.

E para aqueles que reconhecem a importância das Pessoas que passam por suas vidas [...] ". Clarice Lispector 


\section{RESUMO}

A presente revisão de literatura tratou da desidratação de hortaliças, um processo baseado na transferência de calor e massa, permitindo a redução da disponibilidade de água no alimento. Como conseqüência, as condições tornam-se desfavoráveis para que ocorram reações enzimáticas, químicas e o desenvolvimento de microrganismos. $O$ trabalho procurou mostrar as diversas finalidades em que a desidratação de hortaliças é empregada, abordando os processos de secagem natural e artificial usados, assim como as vantagens e desvantagens de cada processo e o impacto dos seus efeitos sobre elas. Observou-se que a desidratação artificial obteve uma notoriedade maior em virtude do controle das condições de secagem. Assim como todo o processo de conservação, a desidratação ocasiona modificações indesejáveis nos aspectos sensoriais como cor, sabor e textura das hortaliças, e perdas de alguns elementos nutritivos, especialmente vitaminas. A desidratação também se apresenta como uma das diversas alternativas existentes para aproveitar o excesso da produção, transformando esse excedente em vários produtos.

Palavras - Chave: 1. Hortaliças 2. Desidratação 3. Microrganismos. 


\begin{abstract}
The dehydration of vegetable was proposed about the present revision of literature, this process is based on the heat transference and mass, allowing the reduction of the content water availability in the food. As consequence, the conditions become favorable for enzymatic and chemical reactions that contribute the development of the microorganisms. The work searched to show different purposes where the dehydration of vegetable can be use, approaching the used processes of natural and artificial drying, as such as the advantages and disadvantages of each process and the impact of its effect on them. It was observed that the artificial dehydration got a bigger notoriety in virtue of the control of the drying conditions. Therefore, every conservation process, the dehydration causes modifications undesirable in the organoleptic properties as color, flavor and texture and the nutritional elements of the vegetables droughts. The dehydration is one of the possibilite to use excess of the production, transforming it in others products.
\end{abstract}

Keys words: 1. Vegetable 2. Dehydration 3. Microorganism. 


\section{LISTAS DE FIGURAS}

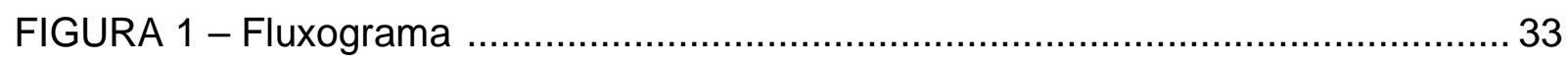

FIGURA 2 - Desidratador tipo cabine ……………........................................ 43

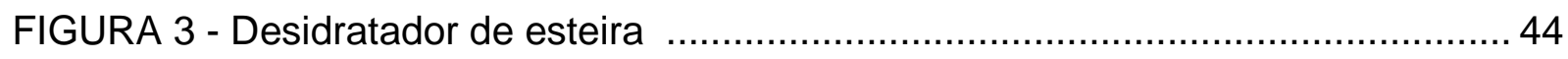

FIGURA 4 - Desidratador de leito fluidizado …………............................................... 45 


\section{LISTA DE TABELAS}

TABELA 1 - Modificação dos pigmentos de hortaliças pela cocção 22

TABELA 2 - Composição físico-química dos pós desidratados de beterraba, abóbora e cenoura 24

TABELA 3 - Algumas limitações dos métodos tradicionais de preservação dos alimentos baseados em um tipo de obstáculo. 27

TABELA 4 - Duas interpretações das interações de água-soluto 28

TABELA 5 - Valores mínimos de atividade de água (Aa) para o crescimento de bactérias, bolores e leveduras em condições ótimas de cultivo 31 


\section{LISTA DE ABREVIATURA E SIGLAS}

Aa - Atividade de água

Ago. - agosto

Agrotec. - Agrotecnologia

Aliment. - Alimentos

Ampl. - ampliada

ANVISA - Agência Nacional de Vigilância Sanitária

apud - citado por

B. - Boletim

Braz. - Brazilian

CAPES - Coordenação de Aperfeiçoamento de Pessoal de Nível Superior

CET - Centro de Excelência em Turismo

Ciênci. - ciência

cv. - cultivar

Coord. - Coordenador

ed. - edição

et al. - e outros

INCA - Instituto do Câncer

J. - Journal 
Jun. - junho

Jul. - julho

Mar. - março

n. - número

Out. - outubro

p. - página

Rev. - revista

RS - Rio Grande do Sul

SBCTA - Sociedade Brasileira de Ciência e Tecnologia de Alimentos

SCIELO - Scientific Electronic Library Online

SENAI - Serviço Nacional de Aprendizagem Industrial

Set. - setembro

Technol. - Technology

Tecnol. - Tecnologia

V. - volume

Dez. - dezembro 


\section{LISTA DE SÍMBOLOS}

${ }^{\circ} \mathrm{C}-$ Graus Celsius

$\%$ - Porcentagem

$\mathrm{m} / \mathrm{s}$ - Metro por segundos

Cl - Cloro

Na - Sódio

pH - Potencial hidrogeniônico 


\section{SUMÁRIO}

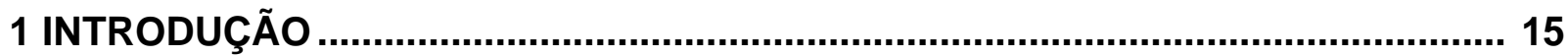

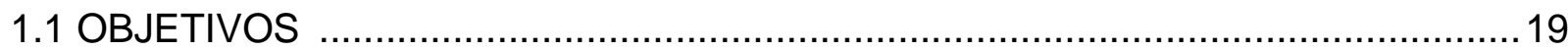

1.1.1 Geral

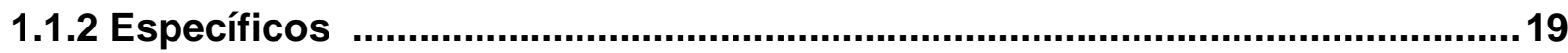

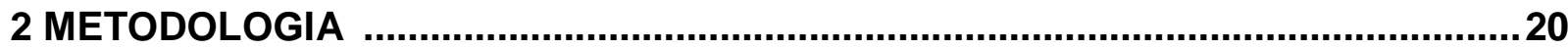

3 REFERÊNCIAL TEÓRICO.............................................................................. 21

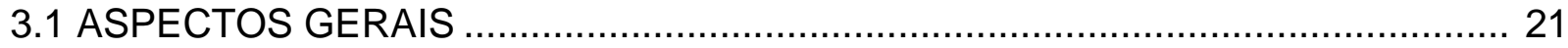

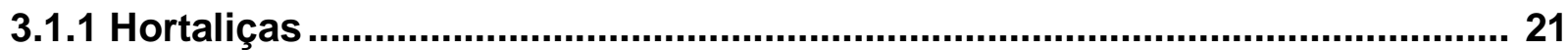

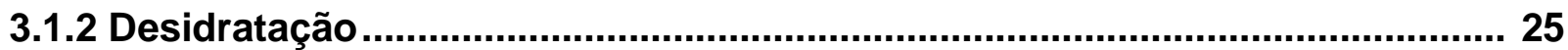

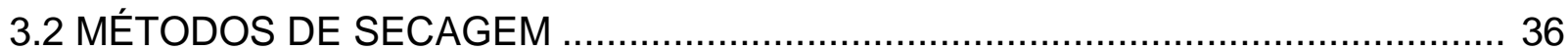

3.2.1 Secagem natural.................................................................................... 38

3.2.1.1 Equipamentos utilizados na secagem natural ..................................... 39

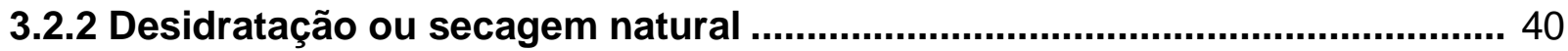

3.2.2.1 Equipamentos utilizados na desidratação .................................................. 41

3.3 ALTERAÇÕES PROVOCADAS PELA DESIDRATAÇÃO ................................ 45

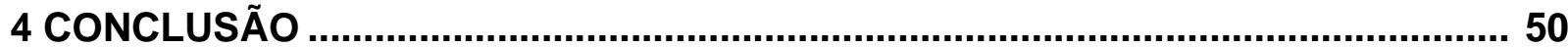

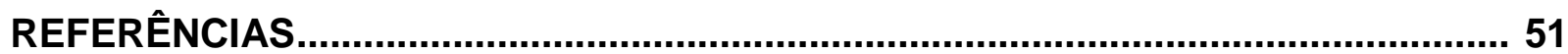




\section{INTRODUÇÃO}

As condições climáticas do Brasil e as distâncias entre os centros de produção e consumo são fatores relevantes que justificam o uso de métodos artificiais para estender a vida de prateleira dos alimentos perecíveis - como as hortaliças, principalmente quando há necessidade de transportá-los de um lugar para outro percorrendo longas distâncias, evitando, assim, que eles se deteriorem com mais facilidade (ORNELLAS, 2001).

Nesse percurso é importante lembrar a importância dos alimentos para a manutenção da vida do ser humano. É a partir dos alimentos que obtemos os elementos nutricionais e calóricos, tais como carboidratos, proteínas, lipídios, fibra alimentar e minerais entre outros, necessários para o bom funcionamento do organismo, visando à alimentação saudável. Quando se fala em alimentação saudável é comum à recomendação para ingerir alimentos ricos em fibras, pobre em gordura e, preferencialmente, rica em frutas e verduras (SANTOS et al., 2002).

As hortaliças são alimentos perecíveis; estragam facilmente e apresentam altos índices de perdas pós-colheita. Segundo ${ }^{1} T$ sunechiro et al. (1994), apud Vilela e Henz (2000), perdas agrícolas são definidas como 'reduções na quantidade física do produto disponível para consumo, que podem vir acompanhadas por uma redução na qualidade, diminuindo o valor comercial ou nutritivo do produto'.

Para atender à demanda de uma classe de consumidores cada vez mais exigentes com a qualidade e inovação tecnológica, a indústria alimentícia tem se aprimorado para atender a essas exigências ofertando novas categorias de produtos com requintes de qualidade e sofisticação.

O mercado de hortaliças vem se estruturando em diversos segmentos, apresentando novas tendências de consumo e expansão de novos mercados. Hoje, podemos encontrar também no mercado, além dos tradicionais produtos in natura, produtos orgânicos, minimamente processados, congelados, supercongelados, conservas, enlatados, desidratados e liofilizados (VILELA; HENZ, 2000).

\footnotetext{
${ }^{1}$ TSUNECHIRO, A.; UENO, L. H.; PONTARELLI, C. T. G. Avaliação econômica das perdas de hortaliças e frutas no mercado varejista da cidade de São Paulo, 1992-92. Agricultura em São Paulo, v. 41, n. 2, p. 1-15, 1994.
} 
A elaboração de novos produtos constitui alternativa para agregar valor e atender as inúmeras divergências entre as preferências do consumidor. Observa-se que todos os novos produtos são alternativas para a conservação das hortaliças.

Caliari et al. (2004) observaram ainda que a conservação de hortaliças prioriza, como um dos objetivos principais, o desenvolvimento de produtos com uma maior vida de prateleira, cujas propriedades sensoriais e nutritivas se aproximem ao máximo aos das hortaliças in natura.

$\mathrm{Na}$ abordagem da conservação de alimentos, nota-se que a desidratação continua a promover o desenvolvimento de novas tecnologias, produtos $\mathrm{e}$ ingredientes para a indústria de alimentos (SANTOS, 2005).

Nesse sentido, a desidratação demonstra ser uma técnica viável para aproveitar o excedente da produção, disponibilizando para o mercado consumidor produtos estáveis e seguros. Além de possibilitar uma alternativa de renda para agricultores e pessoas ligadas ao ciclo de produção e comercialização de hortaliças (ROQUE-SPECHT; MAIA, 2002). No geral, a secagem depende da qualidade da matéria-prima para originar produtos com padrões de qualidade aceitáveis.

Segundo Soares et al. (2001), a desidratação de alimentos motiva os investimentos na industrialização de frutas e hortaliças, em função dos benefícios monetários provenientes da oferta de um novo produto no mercado.

A desidratação é, provavelmente, o mais antigo e um dos mais importantes métodos de conservação. Também é importante nas indústrias químicas e de alimentos. A desidratação é a técnica de remoção da água na forma de vapor pela transferência de calor, ou seja, é a conservação do alimento pelo controle da umidade nele presente.

Cruz (1990) corrobora relatando que os primeiros processos de secagem iniciaram-se expondo a carne ao sol, a qual desenvolvia uma camada externa seca, que impedia a penetração dos microrganismos, possibilitando a conservação da parte interna por mais tempo. Torrezan et al. (1997) também reconhecem que as primeiras técnicas envolveram a secagem ao sol ou aquecimento das carnes sobre o fogo, de modo a diminuir o teor de água, conversando o produto por mais tempo. 
Maason e Challet, em 1795, criaram o primeiro método artificial de desidratação usando água quente. À medida que os anos transcorreram, surgiram vários tipos de aparelhos de secagem os quais apresentam os mais variados processos de remoção da água dos alimentos (SENAI-PR, 2000).

Cruz (1990) relata que o processo de desidratação só passou a ser aplicado de forma expressiva nas Guerras Mundiais, produzindo toneladas de mais de 160 vegetais em função da necessidade de suprir as tropas em combate.

Hoje, grande parte dos países desenvolvidos utiliza métodos avançados de secagem e desidratação. Frutas, carnes e vegetais são processados ao sol ou por meio de sistemas artificiais, sendo comercializados no mundo todo. $A$ produção de alimentos desidratados tornou-se uma indústria multimilionária. Infelizmente, a maioria das informações que permitem esse desenvolvimento não tem sido aproveitada no sentido de viabilizar a desidratação de alimentos em pequena e média escala (CRUZ, 1990, p. 22).

Com o resultado dos avanços tecnológicos na área de conservação de alimentos, o mercado tem disponibilizado uma variedade de produtos desidratados que apresentam grande diversificação e aplicação. Como exemplos, temos: sopas instantâneas com vegetais desidratados, sucos de frutas em pó, maçã, abacaxi, manga, banana e cogumelos desidratados e o tomate seco em conserva (SANTOS, 2005). No Brasil, os produtos normalmente secos são carnes, vegetais, frutas, ervas e temperos (EVANGELISTA, 1998).

As hortaliças desidratadas dão origem a inúmeros produtos, alguns deles de elevado consumo no Brasil como sopas e pós-desidratados. A desidratação de hortaliças proporciona, além de baixo custo, produtos que conservam, com pouca alteração, suas características organolépticas e nutritivas (MOTA, 2005).

Vilela e Henz (2000) afirmam que as hortaliças desidratadas e liofilizadas (que também inclui as frutas) apresentam um consumo médio anual da ordem de 1.300 toneladas, sendo a produção destinada à fabricação de sopas e de molhos. 
Sabe-se que a qualidade dos alimentos desidratados sofre alterações no decorrer do armazenamento devido a várias reações que continuam a ocorrer mesmo após o processamento. Em geral, a qualidade dos produtos desidratados sofre alteração com o tempo de armazenamento. Deve-se ressaltar que a vida de prateleira dos produtos desidratados está intimamente relacionada com a embalagem e as condições de armazenamento. É importante evitar a passagem de oxigênio, luz e umidade para essa categoria de alimentos devido estes fatores alterarem sua estrutura.

Cabe destacar que durante o transporte e o armazenamento dos produtos submetidos à secagem, eles necessitam, nessas fases da cadeia produtiva, de embalagem adequada de modo a manter as características do produto obtidas na secagem. Grosso modo, pode-se afirmar que embora os produtos desidratados se beneficiem pela remoção da água, que possibilita a inibição do desenvolvimento de microrganismo e o aumento na vida de prateleira, a embalagem é extremamente importante para garantir a estabilidade dos produtos desidratados (EVANGELISTA, 1998).

A capacidade de resistência ao cozimento do vegetal desidratado, o sabor, a maciez e a textura estão relacionados com a boa qualidade do produto fresco, preparação, pré-tratamento e método de secagem adequado, além das condições de armazenamento. O vegetal, salvo raras exceções, leva bastante tempo para reidratar e só se torna comestível após ser reidratado, o que difere das frutas (CRUZ, 1990).

A desidratação dos alimentos causa, em geral, poucas alterações, sendo algumas delas desejáveis, como a perda de água, com a conseqüente concentração dos nutrientes por unidade de peso. As propriedades organolépticas, principalmente a textura, e o valor nutritivo, especialmente, as vitaminas, são afetadas negativamente quando expostas às altas temperaturas em tempo prolongado, porém as perdas são pequenas. Todavia, a remoção de água é um eficiente método utilizado no controle do desenvolvimento de microrganismos, visto que este constituinte é imprescindível para as atividades metabólicas de todas as formas de vida (SILVA, 2000). 
No entanto, quando a operação de desidratação for indevidamente realizada permite falhas no processo o que pode desencadear condições para a proliferação microbiana, principalmente os microrganismos anaeróbios, causando a contaminação do produto e tornando-o impróprio para consumo.

Nesse contexto, é importante lembrar que a desidratação de alimentos por meio de técnicas adequadas é cientificamente apropriada, sendo objeto de muitas pesquisas na procura de métodos de secagem que proporcionem poucos efeitos indesejáveis ao alimento, já que oferece alterações desejáveis que melhoram a qualidade do produto.

\subsection{OBJETIVOS}

\subsubsection{Geral}

A presente revisão de literatura apresentou, como objetivo principal, rever os processos de desidratação utilizados em hortaliças.

\subsubsection{Específicos}

- Descrever os processos de desidratação utilizados em hortaliças.

- Identificar em quais hortaliças se emprega os processos de desidratação.

- Apontar o cenário atual de hortaliças desidratadas nos mercados consumidores.

- Correlacionar o processo de desidratação com os outros métodos de conservação de alimentos.

- Mostrar o impacto dos efeitos da desidratação sobre as hortaliças. 


\section{METODOLOGIA}

Este trabalho consistiu em uma revisão de literatura e toda a documentação da pesquisa abrangeu os últimos setes anos, ou seja, textos elaborados entre 1999 a 2006. No entanto utilizou-se de textos clássicos referentes ao assunto abordado e que não se enquadram no período estabelecido.

Após a definição e o esboço do projeto foi feita uma busca em sites com bases de dados tais como capes, scielo, universidades, instituições de pesquisas e outros; também foi realizada busca de artigos científicos em revistas como: Ciência e Tecnologia de Alimentos, Biologia e Ciências da Terra, Bragantia, Brazilian Journal of Food Technology, Higiene Alimentar e outras, assim como o uso de livros da área de ciências e tecnologia de alimentos e de nutrição para obter informações sobre o tema.

Os textos foram extraídos de sites, revistas e livros encontram-se nos idiomas português, inglês e espanhol. As principais palavras chaves utilizadas para a pesquisa foram: hortaliças, desidratação, secagem, curva de secagem e desidratação de hortaliças.

O material coletado abrangeu todo o tema desde os aspectos gerais da desidratação até as conseqüências das alterações sofridas pelas hortaliças neste processo. 


\section{REFERÊNCIAL TEÓRICO}

\subsection{ASPECTOS GERAIS}

\subsubsection{Hortaliças}

A Agência Nacional de Vigilância Sanitária (ANVISA) define, na Resolução RDC № 272, que "hortaliça é a planta herbácea da qual uma ou mais partes são utilizadas como alimento na sua forma natural". Em outras palavras, as hortaliças compreendem as partes comestíveis das plantas, como raízes, tubérculos, rizomas, caules, folhas, flores, frutos e sementes (BRASIL, 2005).

As hortaliças recebem as seguintes designações: verduras, quando utilizadas as partes verdes; legumes, quando utilizados os frutos ou as sementes, principalmente das leguminosas e raízes; tubérculos e rizomas, quando são utilizadas as partes subterrâneas (BRASIL, 2005). Essa designação também é utilizada na classificação das hortaliças, baseando-se na parte da planta que é utilizada como alimento.

A pigmentação das hortaliças pode ser usada também para classificá-las em: hortaliças verdes, cuja cor é dada pela clorofila (alface, couve, rúcula); hortaliças amareladas e alaranjadas, cuja cor é dada pelo caroteno e pela xantofila (cebola, abóbora, batata baroa); hortaliças vermelhas, cuja cor é dada pelo licopeno (tomate, pimentão); hortaliças vermelho-arroxeadas, cuja cor é dada pela antocianina (beterraba, repolho-de-bruxelas); hortaliças brancas e branco-amareladas, cuja cor é dada pelas flavinas ou flavonas, como a encontrada na couve-flor (ORNELLAS, 2001). Todos esses pigmentos podem sofrer transformações em suas estruturas durante o processamento térmico e armazenamento do alimento, os quais provocam alterações na sua coloração (Tabela 1).

Os vegetais, em geral, são considerados alimentos reguladores e protetores do organismo humano, pois contêm nutrientes que auxiliam as defesas naturais do corpo. As frutas e hortaliças caracterizam-se como sendo as principais fontes de vitaminas, minerais e fibras. 
As hortaliças constituem excelentes fontes de vitaminas, como A, E, C e complexo $B$, além de minerais, como ferro, cálcio, potássio, magnésio e outros que são indispensáveis ao organismo. Além disso, fornecem fibras que auxiliam no processo digestivo (INCA, 2006).

De forma bastante simplificada, fibra alimentar (fibras vegetais) consiste em duas frações: uma solúvel, que é fermentada pela flora microbiana do intestino, e outra insolúvel, que permanece intacta. $O$ que constituem as fibras são polissacarídeos e substâncias relacionadas indigeríveis mais a lignina, que resistem à hidrólise dos sucos digestivos dos humanos. Todavia, a fibra alimentar está relacionada com a prevenção de doenças e a normalidade digestiva (SANTOS et al., 2002).

Tabela 1. Modificação dos pigmentos de hortaliças pela cocção.

\begin{tabular}{|c|c|c|c|c|c|}
\hline Pigmento & Cor & Hidrossolubilidade & $\begin{array}{l}\text { Ação } \\
\text { ácida }\end{array}$ & Ação álcali & $\begin{array}{l}\text { Ação cocção } \\
\text { prolongada }\end{array}$ \\
\hline Clorofila & verde & pequena & $\begin{array}{l}\text { torna-se } \\
\text { verde- } \\
\text { oliva } \\
\end{array}$ & $\begin{array}{l}\text { torna-se } \\
\text { mais verde }\end{array}$ & $\begin{array}{l}\text { torna-se } \\
\text { verde-oliva }\end{array}$ \\
\hline Caroteno & alaranjado & insolúvel & mínima & mínima & escurece \\
\hline Xantofila & amarela & pouco solúvel & mínima & mínima & escurece \\
\hline Licopeno & vermelho & insolúvel & mínima & mínima & escurece \\
\hline Antocianina & vermelho & muito solúvel & $\begin{array}{l}\text { intensifica } \\
\text { o } \\
\text { vermelho }\end{array}$ & $\begin{array}{l}\text { torna-se } \\
\text { roxo ou } \\
\text { azul }\end{array}$ & não altera \\
\hline $\begin{array}{l}\text { Flavinas ou } \\
\text { Flavonas }\end{array}$ & $\begin{array}{l}\text { branco- } \\
\text { amareladas }\end{array}$ & solúveis & $\begin{array}{l}\text { ficam } \\
\text { brancas }\end{array}$ & $\begin{array}{l}\text { ficam } \\
\text { amareladas }\end{array}$ & $\begin{array}{l}\text { escurecem } \\
\text { e, na } \\
\text { presença de } \\
\text { ferro, ficam } \\
\text { esverdeadas } \\
\text { e pardas }\end{array}$ \\
\hline Taninos & incolor & insolúvel & não altera & escurece & Anula \\
\hline
\end{tabular}

Fonte: ORNELLAS, L. H. (2001).

Fazem parte da sua composição química a água, lipídios, proteínas, fibras, vitaminas, carboidratos, sais minerais, ácidos orgânicos, compostos aromáticos e tanino. As cinco últimas substâncias conferem o sabor característico a cada hortaliça (ORNELLAS, 2001). 
Deve-se notar, todavia, que as hortaliças apresentam uma diversificação no modo de utilização, podendo ser usadas no estado in natura, o que ocorre normalmente, assim como participar como ingrediente na elaboração de um produto, ou ainda transforma-se em um novo produto com modificações acentuadas em seus caracteres organolépticos, além de apresentar um maior período de vida de prateleira.

As hortaliças in natura apresentam uma vida de prateleira curta. Esta compreende o período de tempo decorrido entre a produção e o consumo de um produto alimentício e caracteriza-se pelo nível satisfatório de qualidade (PEREIRA et al., 2004). A partir da industrialização a vida de prateleira dos produtos aumenta em virtude dos métodos de conservação aplicados.

No que se refere à berinjela, a secagem torna-se uma das alternativas para reduzir as perdas pós-colheita e diversificar o seu uso, como a sua transformação em farinhas, podendo ser incorporada em diversos produtos, destacando-se os de panificação. Outro aspecto de relevante importância é que a farinha de berinjela apresenta elevado teor de fibra alimentar, predominantemente de fibras solúveis, alta capacidade de absorção de água, podendo aumentar o rendimento da massa, e a praticidade de moagem. Estas características fazem com que a farinha de berinjela, obtida pelo processo de secagem, torne-se uma excelente alternativa para ser adicionada à farinha de trigo, constituindo a chamada farinha mista (PEREZ; GERMANI, 2004).

É preciso lembrar que a berinjela é muito apreciada na culinária e comestível em diferentes formas de preparo, além de apresentar elevado teor de fibra alimentar, o que a constitui em uma significativa fonte (SANTOS et al., 2002).

Nessas circunstâncias, o tomate merece destaque. Ele é altamente perecível, porém apresenta uma boa compatibilidade com o processo de desidratação, originando um produto com caracteres sensoriais diferenciados do produto in natura e pode ser ofertado aos consumidores em qualquer período do ano. Sendo esse processo uma, dentre várias alternativas, importante por reduzir as perdas e agregar valor à matéria-prima (PEREIRA et al., 2006). Estes autores observam ainda que o tomate seco seja uma via para o aproveitamento do excedente de produção, sendo 
a matéria-prima para a obtenção de tomate em pó apontado como uma das alternativas para o processamento de tomates, além de contribuir para maior vida de prateleira dos novos produtos.

Estudos realizados em tomates demonstram que diversas variedades, por exemplo, santa clara, empire e carmem, apresentam comportamentos semelhantes durante o processo de secagem, havendo a possibilidade de utilizar diversas variedades na fabricação de um produto sem comprometer a padronização do produto final (ROQUE-SPECHT; MAIA, 2002).

É importante notar que a secagem do tomate sob diferentes formas visa obter um produto seco com um custo mais baixo e de melhor qualidade, com o objetivo de expandir o mercado consumidor (ALVES; SILVEIRA, 2002).

As hortaliças desidratadas podem ser transformadas em pós-alimentícios, os quais são cada vez mais utilizados pela indústria de alimentos em decorrência dos baixos custos com a embalagem, transporte, estocagem e conservação, aumentando, ainda, seu valor agregado. Em função disso, a Tabela 2 mostra a composição físico-química dos pós-desidratados de beterraba, abóbora e cenoura (COSTA et al., 2003).

Tabela 2: Composição físico-química dos pós-desidratados de beterraba, abóbora e cenoura.

\begin{tabular}{cccc}
\hline Pós & Beterraba & Abóbora & Cenoura \\
\hline Umidade (\%) & 13,0 & 13,3 & 7,2 \\
Proteína (\%) & 10,6 & 9,5 & 7,2 \\
Lipídios (\%) & 0,4 & 1,0 & 1,2 \\
Fibra (\%) & 16,1 & 7,1 & 12,3 \\
Cinza (\%) & 9,7 & 4,2 & 8,3 \\
\hline
\end{tabular}

Fonte: COSTA et al., 2003.

É preciso notar que a industrialização das hortaliças vem crescendo muito nos últimos tempos devido à demanda cada vez maior por alimentos prontos ou semipreparados, em virtude da mudança do perfil da população em relação aos hábitos alimentares (CALIARI et al., 2004).

Complementando essas exemplificações, é relevante que as hortaliças frescas sejam apropriadas para a desidratação e que alcancem uma reabsorção conveniente após a reidratação. Com base nessa perspectiva, a escolha da 
variedade irá depender de suas características sensoriais, resistência à ação mecanizada e posterior manipulação, adequação para a desidratação e rendimento após a reidratação (ANDERSON, 1992).

As raízes como a cenoura, a mandioca e o rabanete são sensíveis à desidratação, assim como as hortaliças folhosas. Ambas requerem umidade relativa acima de 95\% durante o armazenamento. Em contrapartida, os tubérculos como 0 cará e a batata são mais tolerantes e devem ser armazenados em umidade relativa em torno de $80 \%$ a 95\% (LUENGO; CALBO, 2001).

É importante destacar que a alta perecibilidade da cebola limita sua vida de prateleira, além de ocasionar altas perdas pós-colheita em virtude do elevado teor de umidade. Nessas circunstâncias, a desidratação possibilita o aumento da vida útil do produto, assim como o surgimento de novos nichos destinados à cebola desidratada. Deve-se notar, todavia, que no Brasil a sua produção em nível industrial ainda é insignificante. Por outro lado, justifica-se a produção de cebola desidratada devido a sua utilização como condimento culinário e da ausência do manuseio natural, livrando-se do cheiro desagradável e do efeito lacrimogêneo por causa dos compostos voláteis. Para a indústria, o produto deve apresentar uma coloração clara e conter alto teor de pungência, isto é, a combinação de sabor e aroma (PORTO; PINTO, 2002).

\subsubsection{DESIDRATAÇÃO}

Desde épocas bastante remotas, o homem vem desenvolvendo técnicas e métodos de preservação e conservação dos alimentos no intuito de permitir seu melhor aproveitamento no seu estado natural.

Vários fatores concorrem, com maior ou menor interferência sobre o produto, para garantir a estabilidade e a segurança dos gêneros alimentícios (PEREIRA et al., 2004).

Na conservação dos alimentos, é preciso saber e conhecer os processos de deterioração, alterando as condições do meio que a favorecem. Estas condições estão condicionadas por fatores intrínsecos (características inerentes ao alimento) e extrínsecos (referente ao ambiente que circunda o alimento). Os fatores intrínsecos 
são: $\mathrm{pH}$, acidez, atividade de água ( $\mathrm{Aa}$ ), potencial de oxirredução (Eh), nutrientes, constituintes antimicrobianos, estruturas biológicas e microbiota competidora. Já os fatores extrínsecos referem-se à temperatura ambiente, umidade relativa do ambiente e presença e concentração de gases na atmosfera (FRANCO; LANDGRAF, 1999).

O trecho acima retrata a visão de que todos estes fatores, em combinação, permitem controlar o desenvolvimento dos microrganismos nos alimentos, os quais constituem um dos principais agentes responsáveis pela degradação da matéria orgânica ocasionando graves perdas na cadeia produtiva de alimentos. Nesse sentido, é importante lembrar que a matéria-prima que se encontra em péssimo estado de conservação é inapropriada tanto para a obtenção de produtos alimentícios como para utilização no estado in natura, pois nenhum processo tecnológico irá melhorar a qualidade da matéria-prima.

Seguindo de perto as reflexões de Torrezan et al. (1997) é preciso que se diga que a estabilidade e a segurança dos alimentos, em geral, não são somente baseadas na $\mathrm{Aa}$ contida nos produtos, mas na interação dos efeitos de vários fatores, os quais também influenciam tanto a segurança quanto a qualidade dos alimentos. É por isso que todos os fatores devem ser considerados conjuntamente a fim de assegurar a qualidade dos alimentos.

Assim, produzir e fornecer alimentos de boa qualidade aos consumidores em todas as épocas do ano deve ser um dos objetivos fundamentais para a agroindústria. Cabe destacar que a produção e conservação dos alimentos vêm sendo desenvolvidas ao longo dos tempos. As principais técnicas de conservação dos alimentos são: pasteurização, esterilização e apertização (conservação pelo calor); irradiação (conservação pelo uso da radiação); desidratação e liofilização (conservação pela redução da $\mathrm{Aa}$ ); congelamento e refrigeração (conservação pelo frio), conservação pela fermentação; conservação pelo uso de aditivos, dentre outras (GAVA, 2002; ORDÓÑEZ, 2005; SILVA, 2000). Todas as técnicas ou processos de conservação apresentam limitações na preservação dos alimentos, como mostra a Tabela 3. 
Tabela 3. Algumas limitações dos métodos tradicionais de preservação dos alimentos baseados em um tipo de obstáculo.

\begin{tabular}{|c|c|c|}
\hline Método & Obstáculo & Limitações \\
\hline Secagem & $\mathrm{Aa}$ & $\begin{array}{l}\text { Perda de sabor, formato } \\
\text { e cor; textura pobre; } \\
\text { vagarosa /incompleta } \\
\text { reidratação }\end{array}$ \\
\hline Liofilização & $\mathrm{Aa}$ & Custos \\
\hline Enlatamento & Inativação térmica & $\begin{array}{l}\text { Perda de qualidade, } \\
\text { custo da embalagem e } \\
\text { energia }\end{array}$ \\
\hline Salga & $\mathrm{Aa}$ & $\begin{array}{l}\text { Alto conteúdo de sal, } \\
\text { textura pobre (carnes) }\end{array}$ \\
\hline $\begin{array}{l}\text { Acidificação } \\
\text { (natural/artificial) }\end{array}$ & $\mathrm{pH}$ & $\begin{array}{l}\text { Mudanças de sabor } \\
\text { devido à alta acidez }\end{array}$ \\
\hline Conservadores & Ação antimicrobiana & $\begin{array}{l}\text { Problemas de origem } \\
\text { leaal e de saúde pública }\end{array}$ \\
\hline Refrigeração/Congelamento & $\begin{array}{l}\text { Baixa temperatura } \\
\text { (congelamento }+\mathrm{Aa})\end{array}$ & $\begin{array}{l}\text { Custo de energia, } \\
\text { ausência de cadeia de } \\
\text { frio }\end{array}$ \\
\hline
\end{tabular}

Fonte: TORREZAN et al. (p. 215, 1997).

As técnicas de conservação citadas apresentam efeitos variados nos alimentos, sendo específicas, ou melhor, mais apropriadas para um produto do que para outro devido às conseqüências que cada uma provoca no alimento.

A desidratação ou secagem de um alimento (sólido ou líquido) é a operação de remoção da água nele contida. Porém, no alimento há dois tipos de água (ver Tabela 4): água livre, representada pela atividade de água ( $\mathrm{Aa}$ ) e se encontra na forma disponível, agindo como um solvente e participando das transformações químicas, bioquímicas e microbiológicas, e a água ligada, que não está livre para agir como solvente ou para participar de reações químicas e está ligada a macromoléculas (FRANCO; LANDGRAF, 1999). 
Tabela 4. Duas interpretações das interações de água-soluto.

\begin{tabular}{|c|c|}
\hline TEORIA DE Aa & ESTUDOS ATUAIS \\
\hline $\begin{array}{l}\text { A água disponível para as reações } \\
\text { degradativas é a não ligada. }\end{array}$ & $\begin{array}{l}\text { A água disponível está relacionada com a } \\
\text { mobilidade da água (velocidade de } \\
\text { difusão) no sistema alimentar. }\end{array}$ \\
\hline ÁGUA FORTEMENTE LIGADA: & $\begin{array}{l}\text { A } \text { MOLÉCULA DE ÁGUA NÃO } \text { É } \\
\text { ENERGICAMENTE LIGADA AO SOLUTO }\end{array}$ \\
\hline Constituição (faz parte do soluto) & As ligações são fortes do tipo $\mathrm{H}_{2} \mathrm{O}-\mathrm{H}_{2} \mathrm{O}$ \\
\hline $\begin{array}{l}\text { Está ao redor do soluto. Fortemente } \\
\text { ligada aos grupos ionizáveis }\left(\mathrm{NH}_{3}{ }^{+} \text {, }\right. \\
\text { COO-). Esfera de hidratação ao redor } \\
\text { dos grupos ionizáveis. Associada a } \\
\text { proteínas, pectinas e outros. } \\
\text { Ligações íon-dipolo; dipolo-dipolo. } \\
\text { Está água não atua como solvente e } \\
\text { não é congelável a -40C. Sua } \\
\text { mobilidade não é impedida. }\end{array}$ & $\begin{array}{l}\text { A molécula de água é ligada ao sítio polar } \\
\text { pelas ligações }-\mathrm{H} \text { e em via transitória. } \\
\text { Interação dinâmica. }\end{array}$ \\
\hline $\begin{array}{l}\text { Mobilidade restrita pelo efeito da alta } \\
\text { viscosidade. Estado vítreo pode estar } \\
\text { presente. }\end{array}$ & \\
\hline ÁGUA LIGADA & \\
\hline $\begin{array}{l}\text { Ligada com o soluto; água-soluto, } \\
\text { água-água, ligações de hidrogênio. } \\
\text { Permite a solubilidade e mobilidade } \\
\text { do soluto. Aumento da reatividade. A } \\
\text { solubilidade do soluto está baseada } \\
\text { na Lei de Raoult. }\end{array}$ & $\begin{array}{l}\text { A molécula de água em solução não está } \\
\text { geometricamente estática, mas em } \\
\text { contínuo movimento dinâmico. }\end{array}$ \\
\hline \multicolumn{2}{|l|}{ ÁGUA LIVRE } \\
\hline Pode formar soluções & $\begin{array}{l}\text { A temperatura de transição vítrea, Tg, } \\
\text { aumenta a fluidez do sistema. A } \\
\text { velocidade das reações degradativas } \\
\text { aumenta de diversas ordens de grandeza. }\end{array}$ \\
\hline Interpolar no gel e nos s & \\
\hline
\end{tabular}

De modo geral, pode-se afirmar que a $A a$ dos alimentos frescos $e$ processados é um dos parâmetros que determinam sua classificação em perecível ou estável, além da microbiota capaz de proliferar-se neles. Nessas circunstâncias, os alimentos foram classificados da seguinte maneira: a) alimentos com Aa superior a 0,98 (a maior parte dos alimentos frescos), onde a maioria dos microrganismos pode se desenvolver rapidamente em temperatura ambiente; b) alimentos com $\mathrm{Aa}$ entre 0,98 e 0,93 (leite concentrado, carnes curadas, queijos frescos, pão,), nos quais há inibição do desenvolvimento das bactérias gram negativas, dando lugar as 
gram positivas; c) alimentos com Aa entre 0,93 e 0,85 (alimentos desidratados, queijos maturados), e desenvolvem cocos gram positivos, mofos e leveduras; d) alimentos com $\mathrm{Aa}$ entre 0,85 e 0,60 (alimentos de umidade intermediária como nozes, cereais, frutas secas), seguros do ponto de vista sanitário, embora os mofos possam proliferar-se; e, por último, e) alimentos com Aa inferior 0,60 (doces diversos, leite em pó, bolachas), são microbiologicamente estáveis, ou seja, nenhum microrganismo pode crescer (ORDÓÑEZ, 2005). Os resultados permitem concluir que o valor de 0,60 para Aa é considerado como o limite mínimo para o desenvolvimento de microrganismo (TORREZAN et al., 1997).

Para a compreensão mais ampla de Aa nos alimentos, é necessário conhecer a sua definição. Aa é o quociente entre a pressão de vapor da água no alimento e a pressão de vapor da água pura, à mesma temperatura. Os valores de Aa variam de 0 a 1; considerando que a Aa da água pura é 1,00, os microrganismos só se multiplicam em valores ligeiramente inferiores aquele valor. Contudo, a Aa de um alimento é sempre menor que 1,00 e a simples enunciação do conteúdo da Aa no alimento não indica quais alterações alimentares podem ocorrer (ANDERSON, 1992; FRANCO; LANDGRAF, 1999; GAVA, 2002; ORDÓÑEZ, 2005; SILVA, 2000).

Para Torrezan et al. (1997) a Aa representa a disponibilidade de água para o desenvolvimento de microrganismo, do ponto de vista microbiológico, e para a ocorrência de reações deteriorantes, tais como escurecimento, oxidação, hidrólise. Segundo tal formulação, a Aa constitui um dos fatores mais relevantes para o processamento, conservação e armazenamento de alimentos.

Por exemplo, produtos congelados e desidratados apresentam uma Aa relativamente baixa o que proporciona o desaparecimento da água disponível para os microrganismos. Isto porque, para valores baixos de $\mathrm{Aa}(\mathrm{Aa}<0,4)$, a água encontra-se fortemente ligada e, geralmente, não disponível para as reações deteriorantes (ORDÓÑEZ, 2005).

Portanto, no processo de secagem diminui-se o conteúdo de água livre contida em um alimento até o ponto em que ocorra a inibição dos microrganismos deteriorantes e dos causadores de doença de origem alimentar. 
Todos os microrganismos contêm acima de $80 \%$ de umidade e necessitam de água livre para seu crescimento, tendo uma Aa mínima para o desenvolvimento (Tabela 5). Em geral, as bactérias necessitam de valores de Aa superiores aos valores requeridos pelas leveduras e bolores. Entretanto, a maior parte dos microrganismos não morre pela remoção de água e podem crescer novamente quando o alimento for reidratado (MACHADO, 2006; SILVA, 2000).

As características dos microrganismos indicarão o teor máximo de $\mathrm{Aa}$ e o conteúdo de umidade que o produto deve alcançar no processo de desidratação (ANDERSON, 1992).

Assim, a desidratação ou secagem dos alimentos constitui uma das técnicas de conservação que reduz a quantidade de água presente no alimento, mais precisamente sua atividade de água $(\mathrm{Aa})$. Esta redução impede o desenvolvimento microbiano e inibe a maioria das reações químicas e enzimáticas que provocam alterações no alimento. Portanto, o processo de desidratar alimentos tem como meta básica prolongar sua vida de prateleira com poucas alterações nutricionais e sensoriais.

Segundo Soares et al. (2001), a desidratação de alimentos consiste em um método de conservação que impede sua deterioração e perda do valor comercial possibilitando redução de perdas pós-colheita. Ao mesmo tempo, ocorre o refinamento do alimento, tendo em vista a colocação de um novo produto no mercado.

Alves e Silveira (2002), por exemplo, chamam a atenção para a qualidade do produto seco, sob o ponto de vista dos consumidores, que apreciam as características organolépticas (cor, textura e flavor), aspectos microbiológicos e nutricionais, dando preferência aos aspectos visuais, os quais chamam mais a sua atenção. Contudo, a qualidade dos produtos secos resulta da interação de matériaprima in natura, pré-tratamentos, secagem, armazenamento e consumo final. 
Tabela 5. Valores mínimos de atividade de água (aa) para o crescimento de bactérias, bolores e leveduras, em condições ótimas de cultivo.

\begin{tabular}{|c|c|c|c|}
\hline MICROGANISMO & $\begin{array}{l}\text { Aa } \\
\text { MÍNIMA }\end{array}$ & MICRORGANISMO & Aa MÍNIMA \\
\hline $\begin{array}{l}\text { Bactérias } \\
\text { deterioradas }\end{array}$ & & patogênicas & \\
\hline Moraxella spp & $0,96-0,98$ & $\begin{array}{l}\text { Staphylococcus aureus } \\
\text { (cresc.). }\end{array}$ & 0,83 \\
\hline Acinetobacter spp & $0,95-0,98$ & $\begin{array}{l}\text { Staphylococcus aureus } \\
\text { (produção de enterotoxina) }\end{array}$ & 0,93 \\
\hline Aeromonas spp & $0,95-0,98$ & $\begin{array}{l}\text { Clostridium botulinum tipo A } \\
\text { (crescimento). }\end{array}$ & 0,94 \\
\hline Alcaligenes spp & $0,95-0,98$ & $\begin{array}{l}\text { Botulinum tipo B (produção } \\
\text { de toxina) }\end{array}$ & 0,95 \\
\hline Flavobacterium spp & $0,95-0,98$ & $\begin{array}{l}\text { Botulinum } \\
\text { (crescimento) }\end{array}$ tipo $\quad E$ & 0,97 \\
\hline $\begin{array}{l}\text { Enterobacter } \\
\text { aerogenes }\end{array}$ & 0,94 & Leveduras & \\
\hline Escherichia coli & 0,95 & Saccharomyces rouxii & 0,62 \\
\hline $\begin{array}{l}\text { Pseudomonas } \\
\text { fluorescens }\end{array}$ & 0,97 & S. cerevisiae & 0,90 \\
\hline$P$. aeruginosa & $0,96-0,98$ & Debaryomyces hansenii & 0,83 \\
\hline $\begin{array}{l}\text { Lactobacillus } \\
\text { plantarum }\end{array}$ & 0,94 & Zygosaccharomyces bailii & 0,80 \\
\hline Lactobacillus spp & $0,90-0,94$ & Hansenula spp & $0,89-0,90$ \\
\hline $\begin{array}{l}\text { Pediococcus } \\
\text { cerevisae }\end{array}$ & 0,94 & Rhodotorula spp & $0,89-0,92$ \\
\hline Leuconostoc spp & $0,96-0,98$ & Bolores & \\
\hline Microbacterium spp & 0,94 & Aspergillus niger & 0,77 \\
\hline Micrococcus luteus & 0,93 & A. restrictus & 0,75 \\
\hline Bacillus subtiliza & 0,90 & A. fumigatus & 0,82 \\
\hline $\begin{array}{l}\text { B. } \\
\text { stearothermophilus }\end{array}$ & 0,93 & A. wentii & 0,84 \\
\hline $\begin{array}{l}\text { Bactérias } \\
\text { patogênicas }\end{array}$ & & Penicillum citrinum & 0,80 \\
\hline Salmonella spp & 0,95 & P. chrysogenum & 0,79 \\
\hline $\begin{array}{l}\text { Vibrio } \\
\text { parahaemolyticus }\end{array}$ & 0,94 & P. expansum & 0,83 \\
\hline Bacillus cereus & $0,92-0,95$ & Rhizopus nigricans & 0,93 \\
\hline $\begin{array}{l}\text { Clostridium } \\
\text { perfringens }\end{array}$ & 0,95 & Mucor plumbeus & 0,93 \\
\hline
\end{tabular}

Nessas circunstâncias, há etapas e tratamentos de pré-secagem que antecedem a desidratação, que devem ser realizados em ambientes adequados e com pessoal treinado, além de equipamentos apropriados. 
As operações necessárias em um processamento de secagem são basicamente as mesmas, e incluem operações preliminares à secagem propriamente dita e embalagem (MACHADO, 2006).

São extremamente significativas as etapas que antecedem o processo de desidratação. Dentre elas citamos: recepção; seleção/classificação; lavagem; descasque/corte/retirada de sementes; pesagem; pré-tratamentos (desidratação osmótica, branqueamento, aplicação de conservantes); secagem propriamente dita; armazenamento; comercialização (ver Figura 1).

A seguir serão feitas algumas considerações sobre as etapas mostradas no fluxograma abaixo.

A hortaliça que constituirá a matéria-prima deve ter a mesma qualidade necessária para o uso do produto fresco. Na plataforma de recepção da indústria realiza-se a pesagem da matéria-prima recebida para que no final do processo possam ser efetuados os cálculos do rendimento. Partes estragadas e atacadas por insetos, roedores, doenças, e partes com cor e aparências não uniformes deverão ser removidas. Lotes diferentes com estágios de maturação diversos não podem ser misturados porque resultarão em produtos secos com qualidade inferior. Na seleção ocorre a escolha de produtos mais aptos à secagem e estes deverão estar maduros, frescos e tenros. A escolha de produtos ainda verdes resultará em vegetais desidratados com aspecto e sabor desagradáveis. Depois de selecionados são classificados de acordo com os critérios de cor, forma, tamanho, dentre outros. Em seguida ocorre a lavagem, onde é feita à remoção de impurezas remanescentes e a sanitização. Após a lavagem as hortaliças são descascadas, e cortadas de modo a adequá-las corretamente à desidratação, pois o tipo de corte influencia de forma decisiva no tempo de secagem; também devem ser retiradas as sementes e partes indesejáveis. Os tratamentos pré-secagem usados são: a desidratação osmótica (este processo será descrito com mais detalhes), branqueamento (para muitas hortaliças, é primordial para inativação de enzimas, principalmente as responsáveis pelo escurecimento enzimático, além de preservar a cor natural do produto seco e diminuir o tempo de imersão ou cozimento na reidratação do material) e aplicação de conservantes (realizada após a desidratação osmótica ou após o branqueamento, é necessária, em alguns casos, quando se deseja melhorar a cor e manter as 
qualidades do produto final por mais tempo; são utilizados dióxido de enxofre, ácido ascórbico, ácido cítrico, sal e açúcar). Depois dos pré-tratamentos, realiza-se a desidratação onde os fragmentos de hortaliças são acondicionados em bandejas que são colocadas em um desidratador (cabine, túnel, esteira e/ou leito fluidizado) até obter a umidade final desejada. Após a secagem, o produto final será pesado, acondicionado em embalagens apropriadas que devem ser rotuladas. Este produto poderá ser estocado ou direcionado logo para a comercialização.

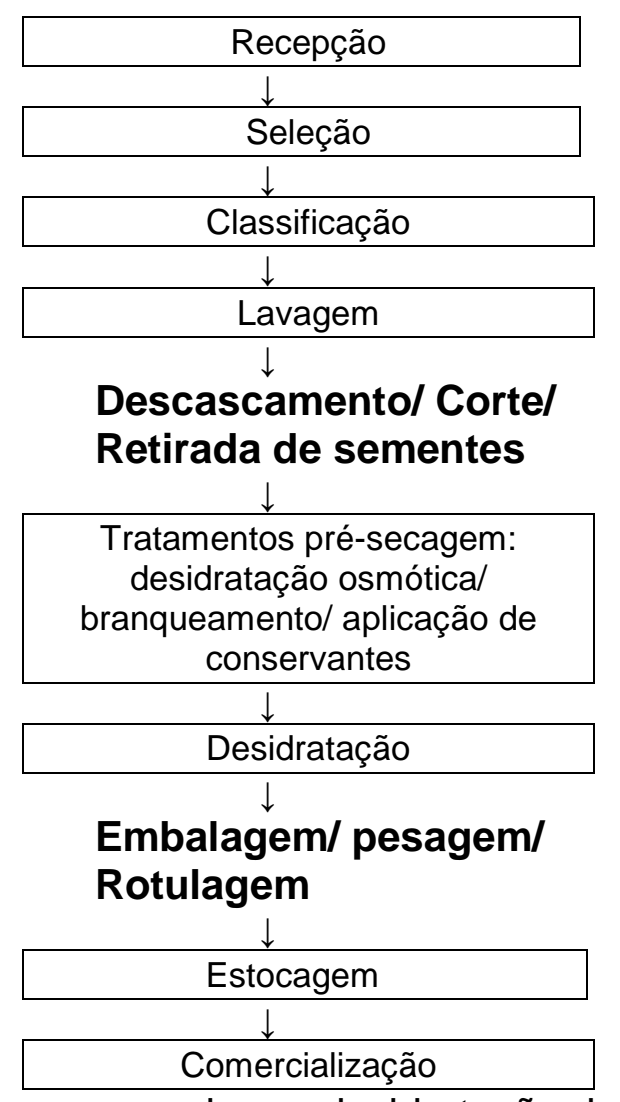

Figura 1. Fluxograma geral para desidratação de hortaliças.

A desidratação por concentração osmótica, ou melhor, desidratação osmótica, é utilizada como um pré-tratamento em vegetais a serem desidratados. O processo ocorre nos tecidos vegetais quando, por exemplo, as hortaliças são colocadas em soluções concentradas de sacarose ou cloreto de sódio $(\mathrm{NaCl})$. À medida que o tempo transcorre a água passa pelas membranas saindo das células e resultando em uma desidratação do tecido. Enfim, a desidratação osmótica permite reduzir o teor de água de um alimento. Esse processo é baseado no fenômeno chamado osmose, que acontece quando duas soluções com concentrações diferentes são separadas por uma membrana que dá passagem a um tipo específico de moléculas 
e não a outras. Isso é possível devido à movimentação de moléculas do solvente através da membrana, no sentido da solução mais diluída para a mais concentrada, até a uniformização das concentrações (CALIARI et al., 2004).

Sousa et al. (2003) observaram que quanto maior o tempo de osmose, maior a perda de água. Contudo, o equilíbrio do conteúdo final de água no alimento com a solução é alcançado pela perda de água dos tecidos do material desidratado. Todavia, a concentração e a proporção produto/xarope na solução influenciam as características do produto assim como o transporte de massa do mesmo.

Nesse sentido, a desidratação osmótica consiste na imersão do alimento sólido em pedaços ou inteiro em soluções hiperconcentradas de um soluto como açúcares ou sais, originando simultaneamente dois fluxos contracorrente: um é à saída de água do produto para a solução devido a diferença na pressão osmótica e o outro é a migração do soluto da solução para o alimento por causa dos gradientes de concentração. Entretanto, a incorporação de soluto é considerada uma desvantagem para o processo quando se busca maior similaridade com o vegetal fresco, e em outros casos é desejável por mascarar a acidez natural dos mesmos. Como alternativa para reduzir a passagem do soluto para o alimento cita-se o uso de cobertura comestível que apresentem alta permeabilidade a água, permitindo seu fluxo para o exterior do alimento, e baixa afinidade pelo soluto, reduzindo sua incorporação. As coberturas comestíveis podem ser à base de alginato, pectinas dentre outras (AZEREDO; JARDINE, 2000; AZOUBEL; MURR, 2000; ORDÓÑEZ, 2005; SOUSA NETO et al., 2005).

As vantagens da desidratação osmótica são a inibição do escurecimento enzimático, retenção da cor natural do produto sem a utilização de conservantes, maior retenção de componentes voláteis durante a secagem subseqüente e menor gasto de energia em relação ao processo tradicional de secagem (MOTA, 2005).

Azeredo e Jardine (2000) constaram que os pedaços de abacaxi revestidos com cobertura comestível obtiveram maior perda de massa, em decorrência da maior perda de umidade e menor incorporação de solutos, o que demonstra a efetividade das coberturas em aumentar a perda de massa do material desidratado. 
Na desidratação osmótica de banana a perda de água e o ganho de sólidos aumentaram de acordo com a concentração inicial de sacarose na solução osmótica (SOUSA NETO et al., 2005).

Entretanto, há perdas de solutos próprios dos alimentos como açúcares, ácidos orgânicos, sais minerais, vitaminas, entre outros, embora sejam quantitativamente menos importantes que as migrações dos fluxos principais na solução osmótica, apesar de modificarem a qualidade organoléptica (flavor, cor e textura) e nutricional (vitamina, mineral) do produto (AZOUBEL; MURR, 2000; ORDÓÑEZ, 2005).

Os elementos que se destacam na desidratação osmótica são os agentes osmóticos e a temperatura. Essa exerce forte influência na desidratação osmótica; em função do seu aumento, há um acréscimo na perda de água, provavelmente em função do fato da membrana celular ter uma perda de seletividade ocorrendo maior difusão do soluto para a amostra. A outra explicação refere-se ao aumento na perda de água devido à diminuição da viscosidade quando se eleva a temperatura do processo (ALVES; SILVEIRA, 2002).

Em princípio, a pré-secagem por desidratação osmótica é aplicada para minimizar os efeitos adversos da secagem. Em função disso, a combinação de métodos de secagem visa assegurar a conservação dos produtos alimentícios de melhor qualidade quando comparado aos produtos desidratados convencionalmente. Assim, a desidratação osmótica surge como uma alternativa promissora em virtude de oferecer uma redução no prejuízo causado pelo calor (SOUSA NETO et al., 2005).

Para alguns autores, a desidratação osmótica é considerada uma ferramenta tecnológica para o desenvolvimento de novos produtos, porém é usada como etapa anterior ao processo de desidratação propriamente dito, porque não remove a maioria da água presente no alimento e, também, não fornece produto com umidade suficientemente baixa para ser considerado estável em prateleira a temperatura ambiente. Portanto, há necessidade de tratamento complementar para eliminar o restante da água existente no produto (ALVES; SILVEIRA, 2002; MACHADO, 2006; SOUSA NETO, et al., 2005). 
Em relação às amostras de tomate submetidas à desidratação osmótica, estas gastam menos tempos de secagem que as amostras in natura. Deve-se notar que os teores de ácido ascórbico e cítrico tiveram menores porcentagens de retenção no tomate desidratado osmoticamente. Em contraste, apresentou uma porcentagem de retenção elevada de licopeno e cálcio, mesmo em relação à secagem (ALVES; SILVEIRA, 2002).

Nessas circunstâncias procurou-se informar que a desidratação osmótica de alimentos remove parcialmente a água através da pressão osmótica e é usada como pré-tratamento no processo de desidratação dos alimentos.

\subsection{MÉTODOS DE SECAGEM}

A secagem pode ser natural, também conhecida como solar, quando expõe o material a ser desidratado ao sol ou sombra, ou artificial que é chamada de desidratação e utiliza calor ou outros meios capazes de retirar a umidade do alimento.

É preciso lembrar que o estudo da influência da Aa sobre os alimentos, com moldes científicos, começou há cerca de quarenta anos. No entanto, há milhares de anos que a Aa é utilizada com o objetivo de prolongar a vida de prateleira dos alimentos (TORREZAN et al.,1997).

Em 1795, na França, surgiu a primeira máquina para desidratar frutas e vegetais por métodos artificiais. A câmera de desidratação funcionava com duplo sistema: um de aquecimento e outro de controle de temperatura (CRUZ, 1990).

As alterações químicas que ocorrem nos alimentos durante a exposição constante ao calor moderado ou temperaturas elevadas, determinam sua perda de valor nutritivo (ROQUE-SPECHT; MAIA, 2002).

A escolha de um método de secagem a ser utilizado vai depender de alguns fatores, entre os quais podemos considerar: matéria-prima (forma e propriedade); propriedades físicas, como cor e sabor desejados para o produto seco; condições e custos de produção; as exigências do mercado e mão-de-obra especializada 
(MACHADO, 2006; SILVA, 2000). A desidratação deve ser o mais rápido possível para assegurar produtos de alta qualidade a um custo razoável.

Outros aspectos importantes são a taxa e o tempo total de secagem, que são influenciados pelas propriedades dos produtos, principalmente tamanhos de partícula e geometria; arranjo geométrico dos produtos em relação ao equipamento; as propriedades físicas do meio secante/ambiente e as características do equipamento de secagem (MACHADO, 2006).

Roque-Specht e Maia (2002), por exemplo, chamam a atenção para a importância do tempo de secagem afirmando que este está relacionado com a economia de energia e tempo e com os aspectos nutricionais. Mesmo usando calor brando $\left(60^{\circ} \mathrm{C}\right)$, mas com tempo prolongado, ocorre des naturação protéica, inativação enzimática e perdas do valor nutritivo dos alimentos.

Devido ao aumento na temperatura, nota-se uma diminuição no tempo de secagem, sendo ela redução mais significativa em se tratando do desidratador de bandejas. Nesse desidratador, a curva de secagem é mais acentuada devido à retirada de água do alimento ser mais efetiva em comparação com os outros tipos de desidratadores (ALVES; SILVEIRA, 2002).

Foi observado, por exemplo, que quanto maior a temperatura de secagem maior a perda de umidade das amostras de cenoura e abóbora, para um mesmo tempo de processo. Contudo, o tipo de matéria-prima pode influenciar favoravelmente na velocidade de secagem. Nesse sentido, as amostras pré-tratadas por congelamento e branqueamento apresentaram uma maior velocidade de secagem quando comparadas com as amostras in natura, nas mesmas condições de temperatura e pressão, embora as amostras congeladas mostrassem maior velocidade de secagem que as branqueadas, pois o congelamento da água modifica as propriedades físicas da matéria-prima o que favorece a secagem. Conclui-se que as amostras de cenoura e abóbora pré-tratadas apresentaram maior velocidade de secagem em virtude de modificarem positivamente a estrutura inicial da matériaprima melhorando a transferência de umidade e aumentando a velocidade de secagem (ARÉVALO-PINEDO; MURR, 2005). 
Nesse sentido, as hortaliças a serem desidratadas são submetidas a cortes pequenos ou de espessura fina com a finalidade de reduzir a distância pela qual o calor tem que passar até atingir o centro geométrico do alimento e que a umidade tem que passar para sair do alimento.

\subsubsection{Secagem natural}

É um método de preservação dos alimentos que consiste na exposição do produto ao sol e ao vento para que ocorra a sua secagem. Os métodos aplicados para esse tipo de secagem são simples e baratos e podem ser realizados pelos pequenos produtores.

As condições climáticas são os principais fatores que determinam a escolha do sistema de secagem a ser utilizado. Nesse caso, a secagem natural está sujeita ao tempo, ou melhor, a um período de insolação adequada e constante. O clima deve ser seco, com grau higrométrico baixo, escassa precipitação pluviométrica, maior período de irradiação solar, boa evaporação, regimes de ventos favoráveis, circulação do ar e temperatura mais ou menos alta. Durante a noite o produto deve ser recolhido a galpões para evitar a umidade noturna. Caso ocorram chuvas há necessidade de abrigar o material para evitar muitas perdas na produção. Para que não haja o desenvolvimento de microrganismos é necessário que as temperaturas sejam relativamente altas e o ar seco (CEREDA, 2003; GAVA, 2002; SILVA, 2000).

Os custos de produção são inferiores ao da desidratação artificial, pois a secagem natural utiliza as condições do meio ambiente. No entanto, não há o controle das condições sanitárias do produto, que fica sujeito à contaminação por poeira, insetos, pássaros e roedores devido ao processo ser realizado a céu aberto.

Este processo pode ser utilizado quando há um excedente na produção e o transporte do produto fresco para outros mercados seja inviável. Porém, para grandes quantidades de alimento o método não é recomendado, uma vez que depende de fatores não controláveis, como o clima (MACHADO, 2006).

Os vegetais não suportam se expor à irradiação solar por mais de um ou dois dias, e podem sofrer queimaduras (CRUZ, 1990). Algumas espécies de frutas e hortaliças são mais adequadas para secagem que outras. 
As áreas reservadas para a secagem dos alimentos devem ser em local limpo, com possibilidade de recolher e proteger o material sempre que chova, ser cercado, com a finalidade de evitar a presença de animais como pássaros, roedores e insetos, e também devem situar-se distante das vias públicas para evitar contaminação (MACHADO, 2006; SILVA, 2000).

A secagem pode ser realizada ao sol e à sombra. Pode ser aplicada em diversos alimentos, tanto de origem animal, como a carne de sol, o charque e os peixes salgados a seco, quanto de origem vegetal, sendo os mais comuns as frutas, leguminosas, cereais, condimentos e especiarias (SILVA, 2000).

A secagem à sombra é empregada para evitar que o alimento fique ressecado, não perca o sabor e o aroma naturais e a sua cor, que fica escura e torna-se marrom se exposto diretamente à luz solar. Podemos citar pimentões, pimentas e ervas como exemplos de alimentos secos à sombra e que mantêm sua coloração atrativa (MACHADO, 2006).

\subsubsection{Equipamentos utilizados na secagem natural}

Os equipamentos empregados na secagem natural são simples e podem ser construídos pelo próprio produtor. Os materiais incluem bandejas ou tabuleiros que possuem molduras de madeira e base em tela de náilon; tendas de polietileno que cobrem as bandejas; cabines e túneis. As bandejas devem ser colocadas em estruturas de apoio na altura de uma mesa, para que facilite a circulação do ar e isole o produto do solo a fim de garantir sua higiene (MACHADO, 2006).

Durante a etapa inicial da secagem, especialmente as primeiras horas do dia, o alimento deve ser virado pelo menos uma vez a cada hora, para que o produto tenha mais uniformidade e a secagem ocorra mais rapidamente. Durante a noite, as bandejas são colocadas em um ambiente ventilado ou cobertas com lona (MACHADO, 2006). Em razão do baixo nível tecnológico e da falta de controle das condições do processo, havendo falhas na secagem do alimento a estabilidade microbiológica ficará prejudicada, afetando a qualidade final do produto. 


\subsubsection{Desidratação ou Secagem Artificial}

A desidratação é a secagem realizada pelo calor produzido artificialmente em condições de temperatura, umidade e corrente de ar cuidadosamente controladas (GAVA, 2002; GEOCITIES, 2006; SILVA, 2000).

Mota (2005) observa que, nos últimos anos, a desidratação de alimentos vem sendo objeto de muitas pesquisas na procura de métodos de secagem que proporcionem, além de baixo custo, produtos que conservem, com pouca alteração, suas características sensoriais e nutritivas.

$\mathrm{Na}$ desidratação, o ar é o meio mais usado na secagem de alimentos em função de sua maior disponibilidade e controle, que não apresenta maiores dificuldades. $\mathrm{O}$ ar leva o calor até o alimento, provocando evaporação da água, e absorve imediatamente o vapor d'água que se desprendeu do produto, sendo também o veículo no transporte do vapor úmido liberado do alimento (CRUZ, 1990; GAVA, 2002; GEOCITIES, 2006).

A velocidade de evaporação da água do alimento irá depender de diversos fatores, tais como temperatura, umidade, velocidade do ar, tipo e a variedade do material, o seu conteúdo em umidade livre, os tratamentos recebidos anteriormente à secagem, tipo de desidratador, área superficial e a porosidade das porções a secar (GAVA, 2002; SILVA, 2000).

O processo de desidratação é de suma importância nas indústrias químicas e de alimentos, como também no armazenamento de grãos e outros produtos biológicos (CAMARGO, 2006).

Cruz (1990) revela que as hortaliças, os tubérculos e as sementes reagem melhor à desidratação, além de reidratarem com mais facilidade do que os talos e as folhas. Entretanto, existem vegetais que, ao serem desidratados, não reidratam satisfatoriamente. É o caso do aspargo, da couve-flor e do brócolis. Deve-se notar, todavia, que o vegetal desidratado só se torna novamente comestível após a reidratação. 
Ornellas (2001) destaca que nos vegetais depois de convenientemente reidratados, usam-se as mesmas formas de preparação empregadas para alimentos frescos. Os vegetais desidratados reduzem de $75 \%$ a $85 \%$ o seu peso inicial. Para os consumidores estes têm sido oferecidos como vegetais folhosos, vagens, cenouras, tomates, cebolas, batatas, aipo, subdivididos em forma granulada, picados ou em pó.

Nesse caso, é importante lembrar as inúmeras vantagens desse processo sobre o que foi descrito anteriormente, dentre elas: rapidez da operação; independência em relação às condições meteorológicas; prevenção do desenvolvimento microbiano; prevenção das alterações químicas ou físicas do alimento, induzidas ou auxiliadas pelo excesso de umidade; redução do peso (50\%$80 \%$ ), em conseqüência da eliminação da água como também pela retirada de partes não comestíveis (cascas, sementes, caraço); menor custo com embalagem, armazenamento e transporte devido à redução de volume; preparação de produtos para processos nos quais somente produtos desidratados possam ser utilizados; remoção da umidade adicionada em operações de processamento; reaproveitamento de produtos; rapidez; facilidade e controle das condições de secagem e sanitárias dentro da câmera de secagem; redução de espaço ocupado e tempo de secagem. Em contrapartida, a desidratação é um processo caro, exigindo um capital maior e mão-de-obra especializada (CEREDA, 2003; FRANCO; LANDGRAF, 1999; GAVA, 2002; SILVA, 2000). Desse modo, pode-se deduzir que cada técnica de conservação de alimentos apresenta suas próprias limitações.

\subsubsection{Equipamentos utilizados na desidratação}

Conhecem-se atualmente inúmeros tipos de secadores ou desidratadores que podem ser utilizados na desidratação de alimentos. O tipo de desidratador a ser escolhido vai depender da natureza da matéria-prima que vai ser desidratada, a forma que se deseja dar ao produto processado, das qualidades a serem mantidas no alimento, da quantidade de material a ser seco, da sensibilidade do alimento à injúria térmica, das características de reidratação, bem como dos aspectos econômicos, exigências do mercado, custo de produção, mão-de-obra, das condições de operações e da umidade final desejada (FRANCO; LANDGRAF, 1999; GAVA, 2002; GEOCITIES, 2006; MACHADO, 2006; SILVA, 2000). 
Cereda (2003) também reconhece inúmeras características que devem influenciar na escolha do desidratador, tais como: facilidade de carga e descarga e, de preferência, operação contínua e automática; distribuição uniforme da matériaprima para melhor aproveitamento do calor; circulação rápida, fácil e uniforme do ar quente, assim como eficiente controle de temperatura e movimentação mecânica da matéria-prima para a obtenção de um produto de qualidade elevada.

Gava (2002) e Silva (2000) relatam que os desidratadores que podem ser utilizados na desidratação de alimentos são agrupados em duas categorias distintas: os desidratadores adiabáticos, que fornecem calor por meio de ar quente, e os desidratadores por contato, que fazem à transferência de calor via superfície sólida. Nos desidratadores adiabáticos estão inclusos os de cabine, túnel, atomizador (spray-dryer), leito fluidizado e os fornos secadores, enquanto que para os desidratadores por contato cita-se o secador de tambor.

Cabe destacar que há os desidratadores a vácuo (liofilização ou criodesidratação), cujo processo é baseado na transformação direta do gelo do alimento em vapor d'água sem passar pelo estado de água líquida (sublimação do gelo). Isso ocorre com a temperatura e pressão de vapor d'água inferiores as do ponto triplo; esse ponto refere-se ao ponto em que coexistem os três estados físicos da água e cujo valor é $0,0099{ }^{\circ}$ C. Portanto, é um processo físico. Mas, deve-se ressalvar que esse desidratador é de uso pouco viável na indústria de alimentos devido ao difícil manuseio e custos elevados com equipamentos e operação (baixas temperatura e vácuo) em relação aos outros tipos de desidratadores (ANDERSON, 1992; GAVA, 2002; ORDÓÑEZ, 2005; SILVA, 2000).

Os equipamentos de desidratação também podem ser classificados de acordo com o fluxo de carga e descarga (contínuo ou descontínuo); pressão aplicada (atmosférica ou vácuo); meios de aquecimento (direto ou indireto); ou ainda de acordo com o sistema utilizado para fornecimento de calor (convecção, condução, radiação ou dielétrico). Por conseguinte, os alimentos podem ser desidratados com ar, vapor superaquecido, a vácuo, por um gás inerte ou pela aplicação direta do calor (GEOCITIES, 2006; SILVA, 2000). A escolha adequada do equipamento de desidratação é fundamental para a obtenção de um produto final de qualidade, com boas características sensoriais e nutritivas. 
A seguir serão descritos alguns dos diversos tipos de equipamentos que mais comumente são utilizados na secagem de hortaliças.

- Desidratadores de bandeja ou cabine ou armário: são constituídos de uma câmara que recebe as bandejas com o produto a secar. Os produtos em camadas finas são colocados uniformemente em bandejas, as quais são perfuradas para facilitar a homogeneização do processo e, em seguida, colocadas sobre vagonetes para sofrer a desidratação. A secagem ocorre por ar aquecido que é impulsionado por meio de ventiladores, por intermédio de aquecedor, passando pelo alimento que está sendo desidratado. Para aumentar a uniformidade do produto, deve-se alternar a posição das bandejas periodicamente. Após o tempo necessário para a desidratação, o produto é retirado. A eficiência térmica nesse tipo de equipamento varia de $20 \%$ a $50 \%$, dependendo da temperatura utilizada e da umidade do ar de saída. É utilizado para a secagem de hortaliças e frutas quando a quantidade a ser seca é pequena, ou seja, servem apenas para operação em pequena escala (GAVA, 2002; GEOCITIES, 2006; MACHADO, 2006; ORDÓÑEZ, 2005; SILVA, 2000).

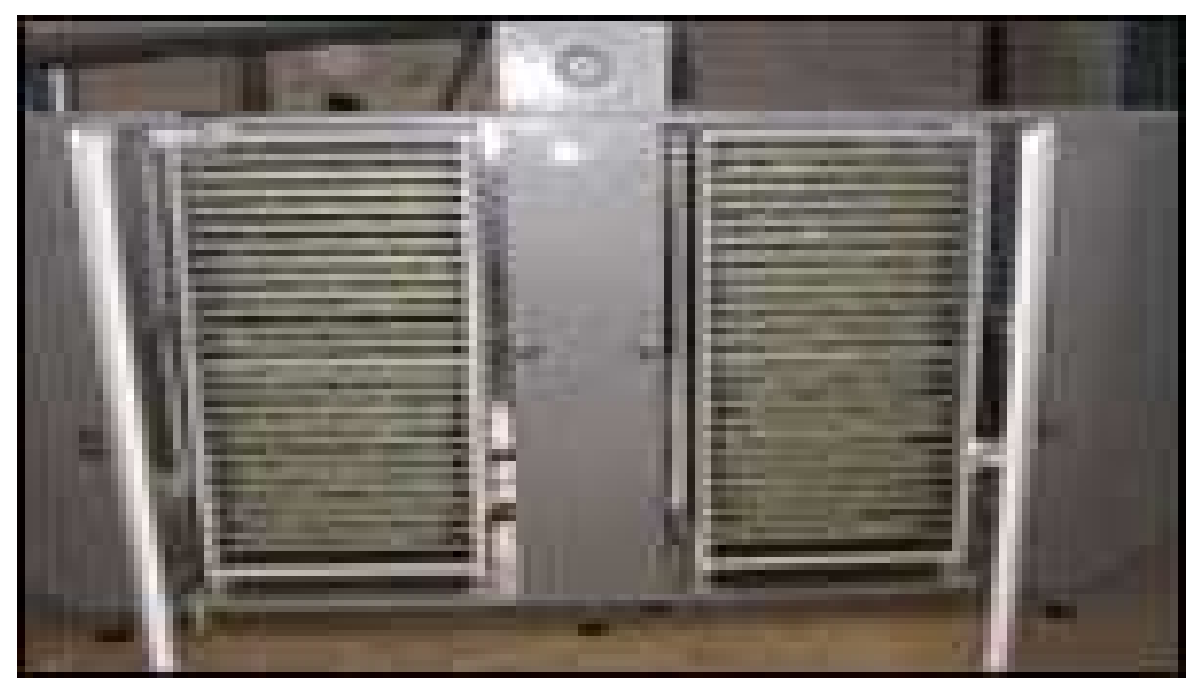

FIGURA 2: Desidratador tipo cabine

- Desidratadores de túnel: são equipamentos em forma de túnel, os quais apresentam tamanhos variados (até $24 \mathrm{~m}$ de comprimento) e permitem a circulação no seu interior de vagonetes ou carros com bandejas contendo camadas uniformes do material a ser desidratado. A disposição das bandejas deve ocorrer de tal maneira que garanta a circulação adequada do ar através de aquecedores. A 
corrente de ar utilizada pode ser natural ou forçada, e em relação à movimentação do produto o fluxo pode ser paralelo, oposto ou combinado. A circulação de ar compreende duas etapas. Na primeira parte, o ar circula no mesmo sentido que o produto e, na segunda, em sentido oposto. A matéria-prima entra por uma das extremidades do túnel e sai por outra, completamente seca. É bastante utilizado na desidratação de frutas e hortaliças, como cebola, alho, batatinha. (GAVA, 2002; MACHADO, 2006; ORDÓÑEZ, 2005; SILVA, 2000).

- Desidratadores de esteira: tem funcionamento muito similar aos de túnel, aos quais estão substituindo progressivamente. São equipamentos com esteiras perfuradas que possibilitam o transporte contínuo do alimento a ser desidratado. Esse transporte é realizado, ao longo do túnel, por uma esteira rolante, sendo a carga e a descarga automáticas. A secagem é mais rápida porque o produto, distribuído em camadas de pouco espessura, tem elevado contato com o ar que atravessa o produto tanto de baixo para cima como de cima para baixo. O produto permanece no túnel até que seu conteúdo de umidade tenha se reduzido em $10 \%$ a $15 \%$. As frutas e hortaliças desidratadas representam a principal aplicação desse tipo de desidratador. As hortaliças, em destaque os legumes, são submetidas a elevadas temperaturas que podem chegar até $130^{\circ} \mathrm{C}$ no primeiro estágio da secagem, sem prejudicar as qualidades dos alimentos devido ao efeito de resfriamento pela evaporação da água (GEOCITIES, 2006; ORDÓÑEZ, 2005).

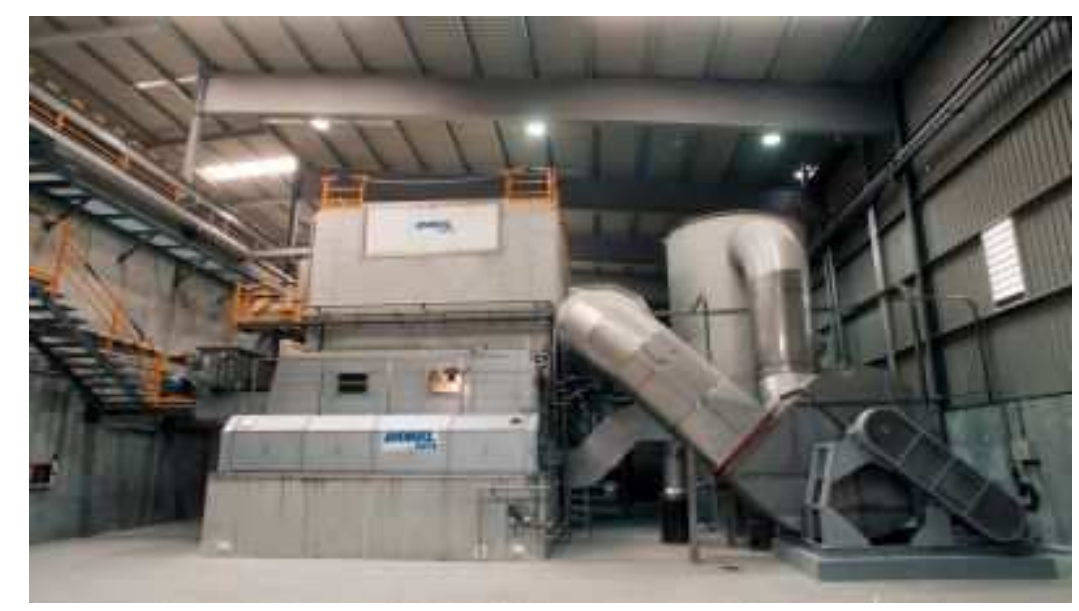

Figura 3. Desidratador de Esteira

Fonte: ANDRITZ, site: <http://www.andritz.com/pg/ANONIDZ0327B5FA4F9F778D/ep-thermal-bds> 
- Desidratadores de leito/base fluidizado: são equipamentos cujo fundo é perfurado e por onde o fluxo de ar quente é introduzido em alta velocidade. Neste caso, o ar atua como meio de desidratação dos produtos como também favorece seu movimento. Este fluxo de ar quente agita vigorosamente (fluidização) o alimento, mantendo-o suspenso no ar e provocando a sua desidratação, ou seja, as partículas permanecem em agitação contínua. Apresenta aplicação limitada devido à adequação do sistema de alimentação para fluidização dos alimentos. Este processo é normalmente utilizado para cenouras, batatas em grânulos, cebola em flocos e outros sólidos suscetíveis de fluidificação (ORDÓÑEZ, 2005; SILVA, 2000).

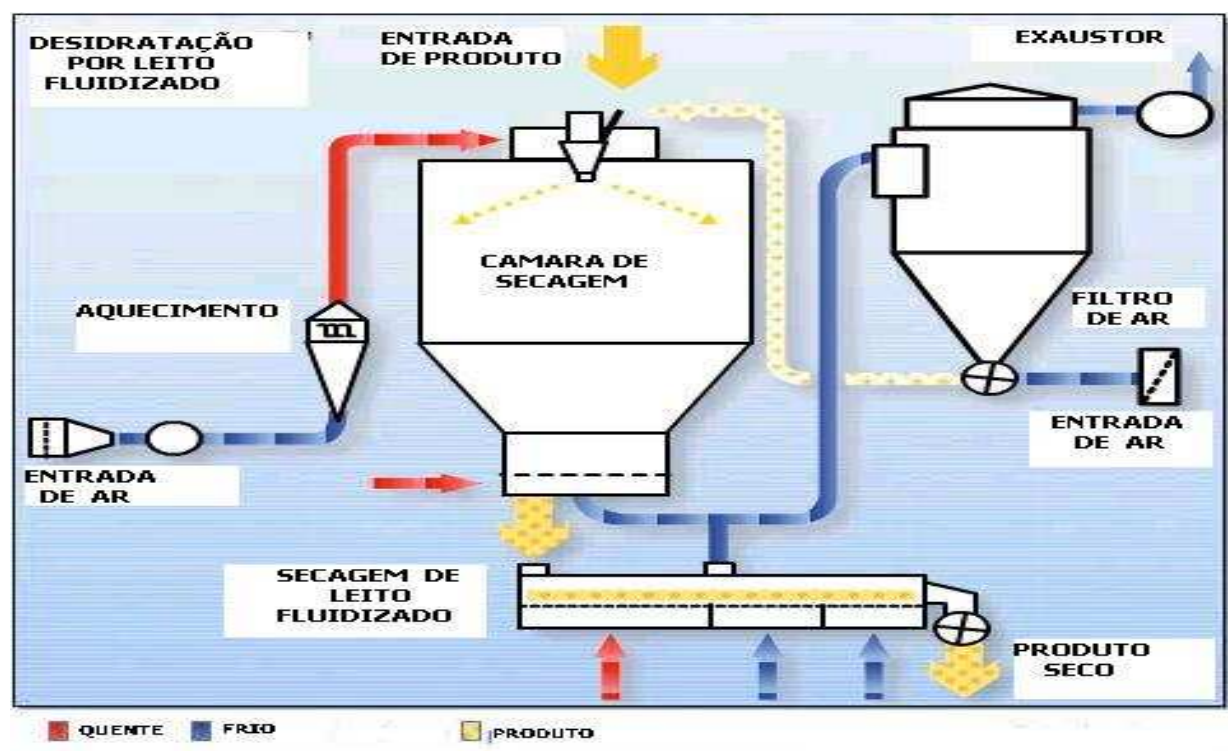

FIGURA 4: Secagem por Leito Fluidizado Fonte: Geocities, 2006.

\subsection{ALTERAÇÕES PROVOCADAS PELA DESIDRATAÇÃO}

Durante a desidratação, os alimentos podem sofrer várias alterações, tanto no seu valor nutritivo como em suas características organolépticas. Mas algumas vezes essas alterações melhoram a qualidade dos produtos.

É preciso lembrar que a maioria das reações enzimáticas está relacionada intimamente com a $\mathrm{Aa}$, tendo um valor de 0,2 a 0,3 para iniciar a manifestação dessas reações. Como sabemos, a água atua como solvente e meio de reação. Em decorrência, a velocidade da reação enzimática depende diretamente da $\mathrm{Aa}$, e à medida que esta aumenta aquela também aumentará. Em contraste com as reações 
enzimáticas, temos as reações de escurecimento não enzimático (reação de Maillard), que também é influenciada pela $\mathrm{Aa}$, sendo que a sua diminuição faz com que a velocidade da reação decaia até valores inferiores a 0,25 (ORDÓÑEZ, 2005).

A diminuição da umidade dos alimentos a um nível considerado seguro elimina a possibilidade de deterioração microbiológica e reduz apreciavelmente a velocidade das reações deteriorantes.

Cruz (1990) destaca que com a perda da água o valor alimentício do produto concentra-se, ou seja, ocorre à concentração dos nutrientes por unidade de peso quando comparado com o produto fresco. $\mathrm{O}$ alimento desidratado é leve, compacto, fácil de transportar, além de manter o sabor inalterado por longos períodos.

O principal problema que ocorre com a desidratação de alimentos diz respeito à possibilidade de perda, mesmo que parcial, de determinados nutrientes, particularmente os suscetíveis ao calor utilizado durante o processo de secagem. É o caso das vitaminas, sendo que algumas são mais sensíveis que outras. A riboflavina é ligeiramente sensível, mas as perdas são pequenas. A tiamina é sensível ao calor e destruída pelos tratamentos com enxofre. A vitamina $C$ também é sensível ao calor e à oxidação, assim como o caroteno. Recomenda-se, muitas vezes, a aplicação de ácido ascórbico para equilibrar o teor de vitamina $C$ que, eventualmente, venha a se perder durante o tratamento, e também prevenir a oxidação. Por outro lado, estas vitaminas se volatilizariam num processo comum de cozimento. As vitaminas lipossolúveis são mais estáveis ao calor e à oxidação (CRUZ, 1990; ORNELLAS, 2001; SILVA, 2000).

Silva (2000) observa ainda que a perda do valor biológico das proteínas depende dos métodos de secagem a que o alimento foi submetido. As baixas temperaturas podem aumentar a sua digestibilidade quando comparada com esse mesmo produto antes da desidratação. Para preservar as gorduras contra os efeitos negativos das altas temperaturas, recomenda-se a utilização de antioxidantes para inibir as reações de oxidação dos ácidos graxos. Os carboidratos não são muito afetados pelo processo de desidratação. 
Cor, textura e sabor do alimento sofrem danos causados pelo calor, sendo a textura a mais afetada devido às altas temperaturas provocarem alterações físicas e químicas na superfície do alimento. Conseqüentemente, a cor é alterada, pois os pigmentos sofrem efeitos negativos por causa da mudança na superfície do alimento e do emprego do calor. O sabor e o aroma sofrem algumas alterações provocadas pela perda de alguns componentes voláteis, os quais conferem o flavor característico de cada alimento (CAMARGO, 2006).

É importante notar a forte influência da Aa sobre a textura dos alimentos. Em alguns casos, esse efeito não é apenas favorável, mas também necessário. Por exemplo, as pipocas, que apresentam a textura típica devido à baixa Aa. Todavia, em outros produtos, é totalmente desfavorável, como no caso das sopas desidratadas, que precisam ser reidratadas antes de seu uso (ORDÓÑEZ, 2005).

São extremamente significativas as alterações que ocorrem com o tomate em pó. Observa-se que a concentração dos açúcares redutores no tomate em pó é maior quando comparada com o teor nos tomate in natura, devido à eliminação de parte da água, o que conduz a uma concentração nestes teores. À medida que prolonga o tempo de armazenamento constata-se que ocorre uma diminuição nos valores dos açúcares redutores decorrente do aumento da umidade no tomate em pó ou pela degradação e/ou transformação destes açúcares em outros açúcares. No que se refere ao teor de ácido ascórbico, este apresentou um bom índice de preservação. $\mathrm{O}$ pH influi diretamente no sabor dos produtos, e é preferível se ter um valor inferior a 4,5 , pois ele impede a proliferação de microrganismos no produto final. Nota-se que os componentes voláteis, formadores de aroma, se mantiveram presentes no produto durante o armazenamento; já em relação à coloração, houve a perda da cor vermelha característica em conseqüência da oxidação dos pigmentos carotenóides e da formação de compostos escuros devido à reação de Maillard (escurecimento não enzimático), principalmente. Para que os tomates secos não sofram alterações de qualidade durante o armazenamento é necessário reduzir a umidade do produto para a faixa que varia de $11 \%$ a $14 \%$, visando evitar o desenvolvimento de microrganismo e manter a estabilidade do produto sem a aplicação de conservantes (PEREIRA et al., 2006). 
Segundo Calbo (2000), as raízes de cenoura cultivar (cv.) Brasília que foram desidratadas a teores relativos de água de até $75 \%$ recuperaram em mais de $60 \%$ a firmeza inicial, ou seja, a firmeza presente antes da desidratação. Isso durante os 67 dias de armazenamento a $5^{\circ} \mathrm{C}$ sob umidade relativa do ar superior a 99\%. Para 0 autor, a recuperação da firmeza é dependente da turgescência celular sem absorção de água, sendo ainda um fenômeno pouco compreendido e conhecido. Também se observou que as raízes de cenouras desidratadas foram capazes de brotar durante o armazenamento. Quando as raízes de cenoura são submetidas à desidratação rápida tornam-se flácidas por causa da redução do teor relativo de água para níveis abaixo de 95\%.

Os dados permitem concluir que a forma na qual as cebolas foram tratadas (picadas, em pasta ou branqueadas) durante a operação de secagem (uso de temperatura do ar de $40^{\circ} \mathrm{C}$ a $60^{\circ} \mathrm{C}$ e a velocidade do ar maior que $1 \mathrm{~m} / \mathrm{s}$ ), exerce influência direta sobre o grau de pungência das amostras, ou seja, as amostras secas em forma de pasta possuem um maior teor de pungência que as cebolas secas picadas. Enquanto isso, as cebolas que foram branqueadas apresentaram baixo teor de pungência, apesar da temperatura de secagem não ser significativa neste caso. No que se refere ao produto seco, nota-se que a forma e a temperatura influenciam diretamente na cor, pois se esses fatores aumentarem, ocorrerá aumento da coloração. Por isso, os produtos com coloração mais escura são destinados para a formulação de molhos, e o produto comercializado somente na forma desidratada deve possuir uma coloração branca a amarelo claro (creme) e um alto teor de pungência (PORTO; PINTO, 2002).

Depois de convenientemente reidratado ou reconstituído, o alimento assemelha-se bastante ao produto natural, dificilmente chegando a igualar-se às condições anteriores devido as eventuais perdas de alguns nutrientes. Para a preparação de hortaliças desidratadas, em qualquer forma que se encontrem, tais como picadas, granuladas e em pó, usam-se os mesmos modos empregados para alimentos frescos (ORNELLAS, 2001).

Para fornecer um produto de melhor qualidade em termos sensoriais e nutricionais é importante que durante a etapa de embalagem o alimento esteja protegido contra a ação da umidade, do ar e da luz. Após a desidratação, a 
conservação do produto dependerá da umidade residual, embalagem, temperatura de estocagem e o tempo de armazenamento (CRUZ, 1990).

O condicionamento do produto seco constitui uma das principais etapas para a devida desidratação, e o objetivo desta etapa é uniformizar a umidade final entre os produtos. Durante a sua realização, não deverá ocorrer condensação da umidade na superfície; caso ocorra, é devido ao teor de umidade ser superior a 25\%, o que acarretará na inadequação do produto para a comercialização (SANTOS, 2005).

Após estas breves considerações, é importante destacar que para a conservação de hortaliças desidratadas as etapas de embalagem e armazenamento posteriores devem ser realizadas de maneira correta para evitar falhas, devido ocasionarem condições favoráveis para que ocorra a deterioração do alimento.

Em resumo, a embalagem e o armazenamento, assim como as demais etapas do processo, devem ser conduzidas cuidadosamente para garantir a boa qualidade do produto para o consumidor.

Por outro lado, deverá ocorrer a inspeção do produto final após o término da secagem para que as extremidades ou partes escuras ou qualquer dano que depreciem a sua aparência sejam eliminados (SANTOS, 2005). 


\section{CONCLUSÃO}

Após essas breves considerações, conclui-se que o processo de desidratação de alimentos, especificamente a desidratação de hortaliças, apresenta inúmeras finalidades para a indústria alimentícia, sendo empregada principalmente na sua preservação. Por intermédio do processo de secagem obtém-se hortaliças desidratadas que podem ser comercializadas dessa forma ou transformadas em pós alimentícios ou tornarem-se ingredientes de um produto, o que confirma a diversificação de sua industrialização e o aperfeiçoamento das condições de processamento.

Constitui também uma das alternativas para aproveitar o excedente de produção, cujo valor será agregado e o produto ofertado em todas as épocas do ano, tendo em vista a redução de custos com certas operações unitárias do processo, além de ocasionar poucas alterações sensoriais e nutritivas nas hortaliças. Dentre estas alterações, chama-se a atenção para as perdas de vitaminas, principalmente aquelas sensíveis ao calor, como a vitamina $C$ (ácido ascórbico) e a tiamina, cujas fontes destes nutrientes se concentram nos vegetais.

Em geral, o processamento faz com que haja perdas, mesmo que parcial, de determinados nutrientes que são relevantes para o organismo humano e, por isso, todo o processamento deve ser realizado minuciosamente para evitar maiores perdas. Portanto, as hortaliças desidratadas estão inclusas na lista de produtos sofisticados, os quais surgem para atender a demanda de uma classe de consumidores cujo mercado está em franca expansão. 


\section{REFERÊNCIAS}

ALVES, S. M.; SILVEIRA, A. M. Estudo da secagem de tomates desidratados e não desidratados osmoticamente. Revista Universidade Rural, Série Ciências Exatas e da Terra, v. 21 (1): 21-30, 2002.

ANDERSON, K. Otros métodos de conservación. In: ARTHEY, D.; DENNIS, C. Procesado de Hortalizas. Zaragoza: Editorial Acribia S.A., 1992. p. 175-211.

ARÉVALO-PINEDO, A; MURR, F. E. X. Influência da pressão, temperatura e prétratamento na secagem a vácuo de cenoura e abóbora. Ciênc. Tecnol. Aliment., Campinas, v. 25, n. 4, p. 636-643, out./dez., 2005.

AZEREDO, H. M. C.; JARDINE, J. G. Desidratação osmótica de abacaxi aplicada à tecnologia de métodos combinados. Ciênc. Tecnol. Aliment., Campinas, v. 20, n. 1, p. 74-82, 2000.

AZOUBEL, P. M.; MURR, F. E. X. Mathematical Modelling of the Osmotic Dehydration of Cherry Tomato (Lycopersicon esculentum var. cerasiforme), Ciênc. Tecnol. Aliment., Campinas, v. 20, n. 2, p. 228-232, 2000.

BRASIL. Agência Nacional da Vigilância Sanitária - ANVISA. Resolução RDC no 272 de 22 de setembro de 2005. Regulamento Técnico para Produtos de Vegetais, Produtos de Frutas e Cogumelos Comestíveis, revogando a resolução - CNNPA no 12, de 24 de julho de 1978. Diário Oficial da União, Brasília 23 de setembro de 2005.

CALBO, A. G. Influência da desidratação na recuperação da firmeza e na brotação em cenoura. Bragantia, Campinas, v. 59, n. 1, 2000.

CALIARI, M. et al. Desidratação osmótica de batata baroa (Arracacia xanthorrhiza). Pesquisa Agropecuária Tropical, 34 (1): 15-20, 2004.

CAMARGO, G. A. Processo produtivo de tomate seco: novas tecnologias (manual técnico). Workshop Tomate na Unicamp, 28 de maio de 2003. Disponível em: < www.agr.unicamp.br/tomates/pdfs/wrktom030.pdf >. Acesso em: 21 jun. de 2006.

CEREDA, M. P. Raspas, farinha de raspas e derivados. In: (Coord.) Tecnologia, usos e potencialidades de tuberosas amilácéas Latino Americanas. São Paulo: Fundação Cargill, 2003. p. 657-681. (Série Culturas de Tuberosas Amiláceas Latino Americanas, v. 3).

COSTA, J. M. C. da et al. Isotermas de adsorção de pós de beterraba (Beta vulgaris L.), abóbora (Cucurbita moschata) e cenoura (Daucus carota) obtidos pelo proceso de secagem em leito de jorro: estudo comparativo. Revista Ciência. Agronômica, v. 34, n. 1, p. 5-9, 2003.

CRUZ, G. A. Desidratação de alimentos. São Paulo: Globo, 1990. 
EVANGELISTA, J. Tecnologia de alimentos. São Paulo: Atheneu, 1998.

FRANCO, B. D. G. de M.; LANDGRAF, M. Microbiologia dos alimentos. São Paulo: Atheneu, 1999.

GAVA, A. J. Princípios de tecnologia de alimentos. São Paulo: Nobel, 2002.

GEOCITIES. Desidratação de alimentos. Disponível em: $<$ http://br.geocities.com/abgalimtec/desidratacao.html>. Acesso em 21 jun. 2006.

INCA - INSTITUTO DO CÂNCER. Hábitos alimentares. Disponível em: <www.inca.gov.br/conteudo view?id=18\#topo >. Acesso em 06 de jul. 2006.

LUENGO, R. F. A.; CALBO, A. G. Armazenamento de hortaliças. Brasília: Embrapa Hortaliças, 2001.

MACHADO, C. M. M. Processamento de hortaliças em pequena escala. Brasília: Embrapa Informação tecnológica, 2006. "no prelo"

MOTA, R. V. da. Avaliação da qualidade físico-química e aceitabilidade de passas de pêssego submetidas à desidratação osmótica. Ciênc. Tecnol. Aliment., Campinas, v. 25, n. 1, p. 789-794, out.-dez., 2005.

ORNELLAS, L. H. Técnica dietética: seleção e preparo de alimento. 7 ed. rev. e ampl.. São Paulo: Atheneu, 2001.

ORDÓÑEZ, J. A. Tecnologia de alimentos: componentes dos alimentos e processos. Porto Alegre: Artmed, 2005.

PEREIRA, I. E. et al. Características físico-químicas do tomate em pó durante o armazenamento. Revista de Biologia e Ciências da Terra, v. 6, no 1, p. 83-90, 1으 semestre 2006.

PEREIRA, K. S. et al. Análises microbiológicas de manga, cultivar Palmer, congelada e minimamente processada. Higiene Alimentar, v. 18, n. 119, p. 47-50, abril 2004.

PEREZ, P. M. P; GERMANI, R. Farinha mista de trigo e berinjela: características físicas e químicas. B. CEPPA, Curitiba, v. 22, n. 1, p. 15-24, jan./jun. 2004.

PORTO, P. S. da S.; PINTO, L. A. de A. Estudo das características da secagem de cebola (Allium cepa L.) descarte quanto à cor e à pungência. Braz. J. Food Technol., v. 5, p. 73-78, 2002.

ROQUE-SPECHT, V. F.; MAIA, M. S. Avaliação da perda de umidade de cinco variedades de tomate, através de secagem artificial. Higiene Alimentar, v. 16, n. 94, p. 30-32, mar. 2002. 
SANTOS, G. L. dos. Desidratação de Alimentos. SENAI - RS - Departamento Regional, 2005. Disponível em: www.sbrt.ibict.br/upload/sbrt900.pdf. Acesso em: 30 out. 2006.

SANTOS, K. A. dos et al. Composição química da berinjela (Solanum melongena L.). B. CEPPA, Curitiba, v. 20, n. 2, p. 247-256, jul./dez. 2002.

SENAI - DEPARTAMENTO REGIONAL DO PARANÁ. Tecnologia de alimentos Série Qualificação. Editora: SENAI, 2000, 38 p.

SILVA, J. A.: Tópicos da tecnologia dos alimentos. São Paulo: Livraria Varela, 2000.

SOARES, E. C. et al. Desidratação da polpa de acerola (Malpighia emarginata D. C.) pelo processo "foam-mat". Ciênc. Tecnol. Aliment., Campinas, 21(2): 164-170 maio-ago. 2001.

SOUSA, P. H. M. de et al. Influência da concentração e da proporção fruto: xarope na desidratação osmótica de bananas processadas. Ciênc. Tecnol. Aliment., Campinas, v. 23, p. 126-136, 2003.

SOUZA NETO, M. A. de et al. Desidratação osmótica de manga seguida de secagem convencional: avaliação das variáveis de processo. Ciênc. Agrotec., Lavras, v. 29, n. 5, p. 1021-1028, set./out., 2005.

TORREZAN, R. et al. Preservação de alimentos com o uso dos métodos combinados: uma revisão. B. SBCTA, 31 (2): 214-228, jul./dez. 1997.

VILELA, N. J.; HENZ, G. P. Situação atual da participação das hortaliças no agronegócio brasileiro e perspectivas futuras. Cadernos de Ciências e Tecnologia, Brasília, v. 17, n. 1, p. 71-89, jan.-abr., 2000. 